\title{
Hydrothermal hydrocarbon gases: 2, Application in the East African Rift System
}

\author{
W.G. DARLING \\ British Geological Survey, Wallingford, Oxfordshire OX10 8BB, UK
}

\begin{abstract}
Hydrocarbon gases are ubiquitous in the hydrothermal systems of the East African Rift System (EARS), though often found at very low concentrations in the 'volcanic' eastern branch as compared to the 'sedimentary' western branch. Study of the chemical and isotopic compositions of these hydrocarbons from sites in Kenya, Ethiopia, Djibouti and Uganda reveals considerable homogeneity over hundreds of $\mathrm{km}$ of the various rift units. Consideration of $\mathrm{C}$ and $\mathrm{He}$ isotopic evidence points to a predominantly crustal thermogenic origin for the hydrocarbons, there being no evidence of mantle inputs in either the MORB or 'hotspot' sectors of the EARS.

Temperature information from geothermal wells has been utilised to investigate the relationship between reservoir temperatures and ratios of methane to ethane. The general $C_{1} / C_{2}$ geothermometric relationship proposed in Part 1 of this study (DARLING, this issue) holds reasonably well, and is shown to give results equal to or better than the 'inorganic' gas geothermometers presently in use, both in the wellfields and undeveloped high-enthalpy geothermal areas. Results from low-enthalpy hot spring systems are less well correlated with apparent deep temperatures, but consistent with data from similar systems elsewhere in the world.
\end{abstract}

\section{INTRODUCTION}

Part 1 of this study of light hydrocarbons in hydrothermal systems dealt with data from areas worldwide, and arrived at certain conclusions regarding the origin of the gases and their possible use for geothermometry (DARLING, this issue). Part 2 considers results from the East African Rift System in the context of these findings.

The East African Rift System (EARS) is shown in Fig 1. The eastern branch ('Eastern Rift') contains many areas of geothermal activity, chiefly high-enthalpy and usually found in association with late-Quaternary volcanic centres. The generally rather arid nature of climate in the Eastern Rift has resulted in groundwater levels often a considerable distance below surface, and consequently few areas of significant water discharge. The use of proven cation and silica solute geothermometry techniques is therefore seldom possible. Fumarolic discharges of steam and gas are however fairly common, and in most areas offer the only key to temperature conditions in the subsurface. Various gas geothermometers have been proposed by different researchers (e.g. D'AMORE and PANICHI, 1980; ARNORSSON and GUNNLAUGSSON, 1985), but their application to the comparatively weak fumaroles of the EARS may frequently be inappropriate because the more reactive gases are prone to attenuation while traversing the often large distance from reservoir boil-off to the surface, and because subsurface condensation of steam changes the gas/water ratio. 
Application of a more suitable gas geothermometer to the EARS was therefore a priority. While this is the main topic of this paper, other implications of hydrocarbon gas data are also considered. Although the most detailed observations were made in Kenya (a more general consideration of hydrothermal gases is presented in DARLING et al, 1995), other data from the Eastern Rift in Ethiopia, the active rift zone of Djibouti and the northern end of the Western Rift in Uganda are also presented and considered.

\section{SAMPLING AND ANALYSIS}

Gas samples were collected from geothermal wells, fumaroles and hot springs, using conventional methods. Usually two subsamples were collected at a site: one of free gas, and one over concentrated $\mathrm{NaOH}$ solution in a pre-evacuated vessel to absorb $\mathrm{CO}_{2}$ and $\mathrm{H}_{2} \mathrm{~S}$. Free gas samples only were collected from very weak fumaroles and hot springs.

Analysis of hydrocarbon gases was carried out by gas chromatography using a phaseless porous polymer packed column and a flame ionisation detector. Quoted detection limits varied depending on the type of sample and analytical equipment used. Analysis of $\delta^{13} \mathrm{C}$ in $\mathrm{CH}_{4}$ and $\mathrm{CO}_{2}$ was performed on a VG 602E mass spectrometer, following conversion of $\mathrm{CH}_{4}$ to $\mathrm{CO}_{2}$ over $\mathrm{CuO}$ at $850^{\circ} \mathrm{C}$ by the method of LYON and HULSTON (1984). Overall precisions for sampling-plus-analysis of $\pm 0.5 \%$ and $\pm 0.2 \%$ are estimated for $\mathrm{CH}_{4}$ and $\mathrm{CO}_{2}$ respectively, although the precisions of $\delta^{13} \mathrm{C}_{-} \mathrm{CH}_{4}$ measurements at methane concentrations below $\sim 0.1 \%$ are likely to be lower.

\section{RESULTS}

Results are presented from three different categories: geothermal wells (Table 1), fumaroles (Table 2) and springs (Table 3). A further table provides information on isomeric ratios for each of the three categories (Table 4). Sample locations are shown in Fig 2a-d, which is based on the area boxes shown in the general map of Fig 1 .

The results show that amounts of hydrocarbons rarely exceed 1 percent of the dry gas fraction even when collected in least-contaminated form from geothermal wells; indeed well samples usually have proportionately lower amounts of $\mathrm{C}_{2}$ and higher hydrocarbons than fumarole or spring samples. When plotted as ratios against $\mathrm{CH}_{4}$ (Fig 3a-c), the hydrocarbons have a distribution largely similar to those from hydrothermal systems elsewhere in the world (DARLING, this issue). There appears from Tables 1 and 2 to be no predictable relationship with amount of $\mathrm{CO}_{2}$, which is normally the dominant gas.

Mode of origin as defined by $\delta^{13} \mathrm{C}_{-} \mathrm{CH}_{4}$ is almost without exception of typical organic-poor hydrothermal type (i.e. $\delta^{13} \mathrm{C} \sim-20$ to $-30 \%$ PDB) in the Eastern Rift and Djibouti, but in Uganda appears 
to be of 'mixed' type, with three out of four samples possessing values more depleted than $-35 \%$. This may be related to the much greater sedimentary fill in the Western Rift compared with most of the Eastern Rift. The $\mathrm{CO}_{2}$ 'carrier gas' present in nearly all the studied manifestations appears from its $\delta^{13} \mathrm{C}$ content to have a mantle source (DARLING et al, 1995). Where air contamination exceeds $90 \%$, measured $\delta{ }^{13} \mathrm{C}_{-} \mathrm{CO}_{2}$ values may decline due to the presence of atmospheric or soil $\mathrm{CO}_{2}$, but $\delta^{13} \mathrm{C}-\mathrm{CH}_{4}$ values apparently remain largely unaffected (Fig 4). The only non-contamination-related trend away from the $\mathrm{CO}_{2}-\mathrm{CH}_{4}$ cluster is shown by some of the samples from Uganda, where there is apparently much higher organic productivity. The comparatively depleted values for both $\delta^{13} \mathrm{C}^{-} \mathrm{CH}_{4}$ and $\delta^{13} \mathrm{C}-\mathrm{CO}_{2}$ are consistent with such a source.

In the active rift zone of Djibouti, thermal waters are considered on the basis of their extreme salinity to be of marine origin (SANJUAN et al, 1990). The few data from this zone (D1, Table 1 and D2 and D3, Table 2) show no characteristics to distinguish them from hydrothermal gases of the main rift.

Isomeric ratios for $\mathrm{C}_{4}$ and $\mathrm{C}_{5}$ and ratios of benzene to hexane (Table 4) are on the whole typical of those found worldwide (DARLING, this issue). Any major departures may be due as much to the difficulties of measurement at very low concentrations as to real variations.

\section{DISCUSSION}

Hydrothermal systems in the Eastern Rift typically divide into two kinds: (a) high enthalpy, nearly always associated with the numerous late-Quaternary volcanic centres on the Rift floor and resulting mainly in steam and gas discharges at the surface, and (b) low enthalpy, commonly but not invariably associated with the sides of the Rift and giving a predominantly hot water discharge (ALLEN et al, 1989; ALLEN and DARLING, 1992). The Western Rift also has systems of both types, though much fewer in number on the available evidence (ARMANNSSON and GISLASON, 1983; BOTZ and STOFFERS, 1993; GODFREY and ARMANNSSON, 1995). The high enthalpy sources appear to depend on magmatic heating, while the low-enthalpy sources may be the result of deep circulation or moderately high geothermal gradients, or some combination of the two. The implications of hydrocarbon gas results from both types are now considered.

\section{High Enthalpy Systems}

Gas properties and origins. The composition of hydrocarbon gases from geothermal wells in Kenya (Olkaria and Eburru), Ethiopia (Aluto-Langano) and Djibouti (Asal) is shown in Fig 3a. The results show that $C_{1} / C_{2}$ ratios are all in excess of 100 . The generally low concentrations of hydrocarbons in these high-temperature reservoirs made butane, pentane and $\mathrm{C}_{6}$ unmeasurable in many cases, but where $\mathrm{C}_{6}$ could be measured, concentrations of the same order as for ethane were obtained. These gases 
therefore showed characteristics of other hydrothermal hydrocarbon gases elsewhere (high $\mathrm{C}_{1} / \mathrm{C}_{2}$, high relative concentrations of $\mathrm{C}_{6}$ ) considered in Part 1 of this study (DARLING, this issue). Carbon isotope ratios in $\mathrm{CH}_{4}$ (Table 1) are also similar to those found in other geothermal wells.

Fumarolic gases show similar characteristics (Fig $3 b$ ), though $\mathrm{C}_{1} / \mathrm{C}_{2}$ ratios cover a wider range, particularly in the 10-100 zone. This wider variation is presumed to result from the greater range of geothermal temperatures sampled via fumaroles compared to the restricted, usually $200-300^{\circ} \mathrm{C}$ range of producing geothermal wells. High-enthalpy springs are included in Fig $3 \mathrm{~b}$.

The low concentrations of hydrothermal hydrocarbon gases in the Eastern Rift together with their relatively enriched $\delta^{13} \mathrm{C}_{-} \mathrm{CH}_{4}$ values accords with evidence of relatively little sedimentation. There is however some limited evidence from North and Central Islands in Lake Turkana (K252-255) that the sediments there may be contributing hydrocarbons. The islands are strong hydrothermal centres, or more accurately centres which are exposed much nearer to hydrological base level than most of the others. The $\delta{ }^{13} \mathrm{C}_{-} \mathrm{CH}_{4}$ values from Central Island in particular are significantly depleted in comparison to the strongest centres (Paka, Silali) of the northern Kenya Rift to the south (Table 2). However it is not clear whether this difference is attributable to the presence of lake sediments, or in some way related to variation in reservoir-surface distance between the island and valley centres, since $\mathrm{CH}_{4}$ molar concentrations comparable with those of the islands were measured in some of the Paka and Silali fumaroles.

In Part 1 of this paper (DARLING, this issue) it was noted that hydrothermal gases tend to have higher normal/iso ratios for butane and pentane than sedimentary natural gases, and also that $\mathrm{C}_{1} / \mathrm{C}_{2}$ tended to increase with system temperature. In Fig 5, isomeric data from geothermal wells, fumaroles and springs in the Eastern Rift are plotted against $\mathrm{C}_{1} / \mathrm{C}_{2}$. As $\mathrm{C}_{1} / \mathrm{C}_{2}$ rises, general tendencies are shown towards increases in normal/iso ratio for butane and to a lesser extent pentane, together with an increase in benzene/hexane.

A further indication that hydrothermal gases from the EARS are similar to those from other parts of the world and other geological situations is provided by plotting $\mathrm{C}_{1} / \mathrm{C}_{2}$ data against ${ }^{3} \mathrm{He} /{ }^{4} \mathrm{He}$ (Fig 6). The plot is somewhat complicated by the fact that there are two subsurface ${ }^{3} \mathrm{He}$ sources in the EARS: MORB-like for the Kenya Rift (DARLING et al, 1995) and of hotspot type for Ethiopia and Djibouti (CRAIG et al, 1977; MARTY et al, 1993; DARLING, 1996), and it is therefore not unexpected to see higher $R / R_{A}$ values for given $C_{1} / C_{2}$ ratios in the hotspot samples. Nevertheless it is apparent that in most areas there is no evidence for simple mixing between thermogenic and hypothetical low $\mathrm{C}_{2+}$ 'deep' methane which would result in a curve on Fig 6, and that therefore the relationship is primarily one related to heat flow and consequently temperature (DARLING, this issue; DARLING et al, 1995), raising the possibility that $\mathrm{C}_{1} / \mathrm{C}_{2}$ could be employed as a geothermometer in the EARS. 
$C_{1} / C_{2}$ geothermometer testing. In order to test the applicability of the geothermometric equation proposed in Part 1 of this paper (DARLING, this issue), information on temperature conditions in the deep subsurface is necessary. In the generally arid Eastern Rift, geothermal wells are the most important source of such information. However, assigning a reservoir temperature to an individual well is not straightforward. Maximum temperatures measured following drilling do not necessarily reflect the bulk temperature during production: it is not uncommon for geothermal wells to receive feeds from several levels often with different temperatures. Because of this, solute geothermometry is commonly carried out on produced waters as a means of calculating bulk temperature (FOURNIER, 1989). Indeed, ARNORSSON et al (1990) used this approach at Olkaria. The two main types of solute geothermometer are based on the $\mathrm{Na} / \mathrm{K}$ ratio and silica concentration of the thermal water. The versions considered here are the $\mathrm{Na} / \mathrm{K}$ and quartz geothermometers of FOURNIER (1989). $\mathrm{Na} / \mathrm{K}$ is a relatively slowly equilibrating geothermometer while quartz is a more rapidly equilibrating one. Therefore, whatever mixing processes are occurring in the immediate reservoir, an average of the two indicated temperatures should be a reasonably good indicator of the bulk temperature. Fig 7 shows temperature information for each of the geothermal wells. In $70 \%$ of cases the $\mathrm{Na} / \mathrm{K}$ and quartz temperatures are within $\pm 20^{\circ} \mathrm{C}$ of their average. The validity of this approach can to some extent be tested by comparison with maximum measured temperatures. In $85 \%$ of cases, this is within $40^{\circ} \mathrm{C}$ of the averaged solute temperatures, and therefore the averaging process is generally giving credible results.

The averaged solute temperatures $\left(\mathrm{T}_{\mathrm{as}}\right)$ falling within this $85 \%$ category seem likely to be the most valid and are used to test the $\mathrm{C}_{1} / \mathrm{C}_{2}$ geothermometer. Fig 8 shows a plot of $\mathrm{T}_{\text {as }}$ versus temperatures derived from the following relationship proposed in Part 1 of this paper (DARLING, this issue):

$$
\mathrm{t}^{\circ} \mathrm{C}=57.8 \log \left(\mathrm{CH}_{4} / \mathrm{C}_{2} \mathrm{H}_{6}\right)+96.8
$$

While the $C_{1} / C_{2}$ temperatures tend to be lower than the $T_{\text {as }}$ values, some $90 \%$ of the data points fall within $50^{\circ} \mathrm{C}$, and about half within $25^{\circ} \mathrm{C}$ of the $1: 1$ line. The performance of this $\mathrm{C}_{1} / \mathrm{C}_{2}$ geothermometer can be put into context by comparison with other gas geothermometers. Figure 8 also shows results for the geothermometers of ARNORSSON and GUNNLAUGSSON (1985), covering various permutations of $\mathrm{CO}_{2}, \mathrm{H}_{2}$ and $\mathrm{H}_{2} \mathrm{~S}$ and based on the assumption of certain gas-mineral equilibrium controls, and the empirical geothermometer of D'AMORE and PANICHI (1980), which requires all the above gases plus $\mathrm{CH}_{4}$. The results from these geothermometers vary in consistency, but none is as effective at $\mathrm{T}_{\text {as }}$ prediction as $\mathrm{C}_{1} / \mathrm{C}_{2}$. It may be that in the EARS the required mineralogical controls are not always operating, or (as referred to above) that many of the wells receive inputs from more than one horizon and that some gas geothermometers adjust to lower temperatures more rapidly than others. A further complication is provided by the chlorinity of well waters, because most of the geothermometers of ARNORSSON and GUNNLAUGSSON (1985) are presented in $<500$ and $>500 \mathrm{mgkg}^{-1} \mathrm{Cl}$ versions. It is not 
entirely clear at Olkaria whether an original $<500 \mathrm{mgkg}^{-1} \mathrm{Cl}$ upflow water becomes more saline owing to steam separation or whether a $>500 \mathrm{mgkg}^{-1} \mathrm{Cl}$ upflow becomes less saline owing to dilution by lowsalinity meteoric waters. Accordingly, geothermometers for individual wells have been applied in the correct version for the chlorinity of the well (data from MUNA, 1984 and Kenya Power and Light Company records). This feature is responsible for most of the lower temperature values given at Olkaria and Aluto-Langano by some of the geothermometers (though not the $\mathrm{CO}_{2}$ or D'Amore-Panichi equations).

Application to fumaroles - Olkaria. Testing the $\mathrm{C}_{1} / \mathrm{C}_{2}$ geothermometer by using geothermal well gases does not guarantee that the proposed relationship works as effectively for fumaroles. However, by application to fumaroles in and around the drilled geothermal fields, some assessment of its performance can be made by comparing the calculated temperatures with the known solute geothermometer temperatures of the nearer wells. At Olkaria, most fumaroles are situated along the Ololbutot fault zone (Fig 9). Agreement between fumarole results and well solute temperatures in and around the fault zone is generally good, except for the isolated western fumarole OF-20, adjacent to well OW-301, where the solute temperature is $48^{\circ} \mathrm{C}$ lower than that of the fumarole. While this may have been due to the fact that $\mathrm{OF}-20$ had by some way the lowest measured $\mathrm{CH}_{4}$ and $\mathrm{C}_{2} \mathrm{H}_{6}$ contents in the whole Olkaria area, possibly affecting the accuracy of the ratio, a maximum measured temperature of $299^{\circ} \mathrm{C}$ was noted for this well (HAUKWA, 1984), which would reduce the discrepancy to only $15^{\circ} \mathrm{C}$.

Application to fumaroles - Aluto-Langano and Asal. In Ethiopia, the Aluto-Langano wellfield is situated within the Aluto volcanic complex (Fig 10). Only fumaroles outside the complex were sampled, there being little surface activity within the complex. Outflow from the Aluto hydrothermal system is believed to take place to the south, towards Lake Langano where several hot or boiling springs discharge near the shore. The $\mathrm{C}_{1} / \mathrm{C}_{2}$ temperature calculated for the Gebiba fumarole fits the progression from $\sim 300^{\circ} \mathrm{C}$ solute temperatures in the south-central part of the wellfield to a solute temperature of $\sim 200^{\circ} \mathrm{C}$ at Spring \#2. The fumaroles at Bobessa and Auto, although somewhat nearer the complex than Gebiba, have similar and lower $\mathrm{C}_{1} / \mathrm{C}_{2}$ temperatures respectively, presumably because they are not situated above zones of upflow or outflow as depicted by Na/K data in GIZAW (1993).

At Asal in Djibouti (Fig 2c), a fumarole (D2) close to the centre of the active rift zone gave a $\mathrm{C}_{1} / \mathrm{C}_{2}$ temperature of $250^{\circ} \mathrm{C}$. A-5, the nearest well to $\mathrm{D} 2$, gave measured upper and lower reservoir temperatures of 190 and $355^{\circ} \mathrm{C}$ respectively, but the solute temperature for well $\mathrm{A}-3$, towards the periphery of the rift zone, was more similar at $264^{\circ} \mathrm{C}$ (ZAN et al, 1990). Further inland, a fumarole (D4) adjacent to a $2000 \mathrm{~m}$ deep test well gave a temperature of $242^{\circ} \mathrm{C}$, whereas the maximum measured well temperature was only $120^{\circ} \mathrm{C}$ even at total depth. The only other gas geothermometer which could be applied to this fumarole was that for $\mathrm{CO}_{2}$, which gave a temperature of $148^{\circ} \mathrm{C}$, in better agreement with the well temperature. 
Application to fumaroles - undrilled areas. Outside the wellfields there are few independent data with which to compare temperatures calculated from fumarolic gas data. In this case the only comparison available is the probable temperature distribution. Figure 11 shows histograms of the different geothermometers calculated from the same dataset, based on the fumaroles of Table 2. The results from dual-chlorinity geothermometers are plotted separately because of a general lack of information on likely $\mathrm{Cl}$ values. The distribution of $\mathrm{C}_{1} / \mathrm{C}_{2}$ temperatures is consistent and realistic on the reasonable assumption that most high-enthalpy reservoirs will have temperatures in the $200-300+{ }^{\circ} \mathrm{C}$ range, as they do in the wellfields. The $C_{1} / C_{2}$ temperatures also accord with other geochemical and geological indications (DARLING and TALBOT, 1991; DUNKLEY et al, 1993). Although the higher $\mathrm{Cl}$ versions of some geothermometers give comparable results, it is not always clear that the 'correct' version is being applied in individual cases.

There are two basic reasons why application of the conventional gas geothermometers should sometimes be problematical in Kenya and Ethiopia: firstly, subsurface steam condensation is known from O and H stable isotopic data to be common in the Rift (DARLING et al, 1990; ALLEN and DARLING, 1992), and this would tend to affect the gas geothermometers based on concentration relative to steam. The $\mathrm{CO}_{2}$ geothermometer seems to be particularly influenced, giving temperatures that appear too high. Secondly, because there is a thick unsaturated zone to traverse, there is ample scope for reaction between gases and wall rocks, or for diffusion into pore spaces adjacent to fumarolic conduits. This would account for the often very low or undetectable concentrations of $\mathrm{H}_{2} \mathrm{~S}$ and $\mathrm{H}_{2}$ observed in fumarolic gases in the continental EARS, which means their geothermometers are not always useable. The advantage of the $C_{1} / C_{2}$ geothermometer is that methane and ethane appear to be relatively unaffected by the above processes, and furthermore are easy to detect down to very low concentrations by simple GC methods. An additional advantage is that, unlike the geothermometers considered above, there is no need to know or make assumptions regarding the concentration of chloride or $\mathrm{pCO}_{2}$ in reservoirs, and it is also unnecessary to know concentrations of gases relative to steam.

Application to high-enthalpy springs. Such springs are very scarce in the Eastern Rift, because groundwater levels are generally too low to allow significant surface discharge from high-enthalpy hydrothermal systems. The main example considered in this study is the Abaya springs of southern Ethiopia (E13, Fig 2b). These give a $\mathrm{C}_{1} / \mathrm{C}_{2}$ temperature of $175^{\circ} \mathrm{C}$, which can be compared with $\mathrm{Na} / \mathrm{K}$ and quartz temperatures of 202 and $153^{\circ} \mathrm{C}$ respectively, based on the data of CRAIG et al (1977).

In the Western Rift at Kibiro (Uganda, Fig 2d), the high-enthalpy hot spring gives a $\mathrm{C}_{1} / \mathrm{C}_{2}$ temperature of $196^{\circ} \mathrm{C}$, close to the $\mathrm{Na} / \mathrm{K}$ solute geothermometer temperature of $205^{\circ} \mathrm{C}$, although higher than the quartz temperature of $151^{\circ} \mathrm{C}$ (GODFREY and ARMANNSSON, 1994). When it is considered that this is the only sample from any of the high-enthalpy EARS sources of this study in which the total gas content is dominated by methane (Table 3), it is perhaps surprising that a relationship based on $\mathrm{CH}_{4} / \mathrm{C}_{2} \mathrm{H}_{6}$ at minor 
concentrations should give a realistic temperature. However, this is supported by the hydrocarbon data of BOTZ and STOFFERS (1993) from the Pemba spring site of Lake Tanganyika further south in the Western Rift. While not completely dominant, hydrocarbons amount to some $30 \%$ of the gas phase at this site. The $C_{1} / C_{2}$ temperature of this site is $216^{\circ} \mathrm{C}$, while PFLUMIO et al (1994) considered the actual reservoir temperature to be $214^{\circ} \mathrm{C}$ on the basis of solute geothermometry.

Heavier hydrothermal hydrocarbons in the Lake Tanganyika area gave a radiocarbon age of $25 \mathrm{ka}$ (SIMONEIT, 1994). Assuming that the light hydrocarbon gases are from the same source, it suggests that gas production is from thermal stress on sediments rather than on dissolved organics. Whether this applies in the much less-sedimented Eastern Rift remains open to question.

\section{Low Enthalpy Systems}

Hydrocarbon results from hot spring sources apparently unrelated to high-enthalpy systems are reported in Table 3 and depicted in Fig 3c. Results are generally similar to those for high-enthalpy gases, though because of the low concentrations of dissolved gases, it was not always possible to measure the higher hydrocarbons. Considering the probable differences in temperatures between high and low enthalpy systems, it is notable that the gases should be so similar, in isotopic as well as chemical composition. This suggests the possibility of gases leaking up from hotter reservoirs below the level of more superficial hot water circulation, confirmed to an extent by the high values of ${ }^{3} \mathrm{He} /{ }^{4} \mathrm{He}$ found in some of the springs (CRAIG et al., 1977; DARLING et al, 1995; DARLING, 1996).

However, the high-enthalpy $\mathrm{C}_{1} / \mathrm{C}_{2}$ geothermometer tested above does not apply to those hot springs whose solute geothermometer temperatures suggest maxima of usually little more than $100^{\circ} \mathrm{C}$. When the chalcedony temperatures are plotted against $\mathrm{C}_{1} / \mathrm{C}_{2}$ (Fig 12), it is clear that there is not a well-defined correlation. Nevertheless, when the few similar data available from elsewhere (Colli Albani, GIGGENBACH et al, 1988; Copper River, Alaska, MOTYKA et al, 1989; Mammoth, Wyoming, KHARAKA et al, 1992; Gulf of Suez, STURCHIO et al, 1996) are added, they tend to fall into the same area on the plot as the EARS data. The spread of results probably represents a mixing of gases from various carbon sources in different parts of low-enthalpy geothermal areas, and therefore any geothermometric relationships are likely to emerge only locally.

\section{CONCLUSIONS}

The concentrations of hydrocarbon gases in hydrothermal systems have been determined for a large number of sites in the EARS, principally in the Eastern Rift in Kenya, Ethiopia and Djibouti, but also in Uganda towards the northern end of the Western Rift. Site types included geothermal wells, fumaroles and hot springs. 
All sites (high and low enthalpy) provided hydrocarbon results indicative of a thermogenic origin for the gases, though $\mathrm{CH}_{4}$ samples from Uganda tended to have lighter carbon isotope ratios, probably because of the greater amount of sedimentation in the Western Rift. The available helium isotope data (Eastern Rift only) indicate that while there is a major difference between mantle gas reservoirs, with MORB type in Kenya and 'hotspot' type in Ethiopia and Djibouti, this is not reflected in hydrocarbon concentrations or carbon isotopic values, which remain comparable in both helium provinces. Neither does there appear to be any difference in hydrocarbons depending on whether the hydrothermal fluid is of meteoric or marine origin, although evidence is as yet limited. In both these respects the EARS data resemble those derived from hydrothermal systems elsewhere in the world which were considered in Part 1 of this study (DARLING, this issue)

Ratios of methane to higher hydrocarbons appear to be basically temperature-controlled in the EARS as elsewhere. Deep reservoir temperatures in geothermal wells were in reasonable agreement with the empirical methane/ethane geothermometric relationship proposed in Part 1. This geothermometer also gives a likely distribution of results when applied to fumaroles of the EARS, and is simpler to use than the various 'inorganic' geothermometers.

In low-enthalpy situations, typical of most hot springs in the EARS, a spectrum of hydrocarbon results is obtained similar to that from the wells and fumaroles. In this case, however, a different and much less well-defined relationship between $\mathrm{C}_{1} / \mathrm{C}_{2}$ and temperature at depth seems to apply. Results are typical of the few other low-temperature hydrothermal systems elsewhere in which hydrocarbon gases have been investigated.

Acknowledgements - I thank my colleagues David Allen, Martin Clarke, Peter Dunkley and Martin Smith for their help in the field in Kenya, and Anita Warrington and John Talbot for assistance with isotopic analysis and data processing respectively. Staff of the Kenya Power and Light Company under Messrs Zach Muna and Musa Arusei collected the majority of the geothermal well samples. In Ethiopia and Djibouti indispensable logistic and technical support was provided by the Ethiopian Institute of Geological Surveys and the Institute Superieur d'Etudes et de Recherches Scientifiques et Techniques respectively; I particularly wish to thank Ato Berhanu Gizaw (EIGS) and M. Jama Khabar and M. Xavier Houdart (ISERST) for their efforts. I am also grateful to Dr Halldor Armannsson for collecting additional samples in southern Kenya, Djibouti and western Uganda.

The comments of Drs B.R.T Simoneit, J.A. Welhan and an anonymous referee were of considerable assistance in revising this manuscript. The research described here and in Part 1 arose out of geothermal exploration projects in East Africa funded by the Overseas Development Administration of the UK. This paper is published with the permission of the Director, British Geological Survey (NERC). 


\section{REFERENCES}

ALLEN D.J. and DARLING W.G. (1992). Geothermics and hydrogeology of the Keny Rift Valley between Lake Baringo and Lake Turkana. Brit. Geol. Surv. Rep. SD/91/1.

ALLEN D.J., Darling W.G. and BuRGESS W.G. (1989). Geothermics and hydrogeology of the southern part of the Kenya Rift Valley. Brit. Geol. Surv. Rep. SD/89/1.

ARMANNSSON H. (1994). Geochemical studies on three geothermal areas in west and southwest Uganda. Rep. to UNDESD Proj. UGA/92/002.

ARMANNSSON H. and GiSLASON G. (1983). Geothermal resources of Burundi. Nat. Energy Auth. Iceland Rep. OS-83025/JHD-06.

ARNORSSON S. and GUNNLAUGSSON E. (1985) New gas geothermometers for geothermal exploration calibration and application. Geochim. Cosmochim. Acta 49, 1307-1325.

ARNORSSON S., BJORNSSON S., MUNA Z.W. and BWIRE-OJIAMBo S. (1990) The use of gas chemistry to evaluate boiling processes and initial steam fractions in geothermal reservoirs with an example from the Olkaria field, Kenya. Geothermics 19, 497-514.

BOTZ R.W. and STOFFERS P. (1993). Light hydrocarbon gases in Lake Tanganyika hydrothermal fluids (East-Central Africa). Chem. Geol. 104, 217-224.

CRAIG H., LuPTON J.E. and HoROWITZ R.M. (1977) Isotope geochemistry and hydrology of geothermal waters in the Ethiopian Rift Valley. Scripps Inst. Oceanog. Rep. 77-14.

D'AMORE F. and PANICHI C. (1980). Evaluation of deep temperatures in hydrothermal systems by a new gas geothermometer. Geochim. Cosmochim. Acta. 44, 549-556.

DARLING W.G. (this issue) Hydrothermal hydrocarbon gases: 1, Genesis and geothermometry. Applied Geochemistry.

DARLING W.G. (1996). The geochemistry of fluid processes in the Eastern Branch of the East African Rift System. Ph.D. thesis (unpubl.), Brit. Geo. Surv./Open Univ., U.K.

DARLING W.G. and TALBOT J.C. (1991). Evaluation and development of gas geothermometry for geothermal exploration in the East African Rift System. Brit. Geo. Surv. Tech. Rep. WD/91/72. 
Darling W.G., Allen D.J. and ARMannsson H. (1990). Indirect detection of outflow from a Rift Valley Lake. J. Hydrol. 113, 297-305.

Darling W.G., Griesshaber E., ANDrews J.N., ARMANnSSON H. and ONIONS R.K. (1995) The origin of hydrothermal and other gases in the Kenya Rift Valley. Geochim. Cosmochim. Acta. 59, 2501-2512.

DunKLeY P.N., SMith M., Allen D.J. and DaRling W.G. (1993) The geothermal activity and geology of the northern sector of the Kenya Rift Valley. Brit. Geo. Surv. Res. Rep. SC/93/1.

Fontes J.C., Pouchon P., SAliege J.F. and ZuPPI G.M. (1980) Environmental isotope study of groundwater systems in the Republic of Djibouti. In Arid Zone Hydrology, IAEA, 237-262.

FOURNIER R.O. (1989) Lectures on geochemical interpretation of hydrothermal water. UNU Geoth. Train. Prog. Rep. 10/89, Nat. Energ. Auth., Iceland.

GigGENBACH W.F., MinisSALE A.A. and SCANDIFFIO (1988) Isotopic and chemical assessment of geothermal potential of the Colli Albani area, Latium region, Italy. Appl. Geochem. 3, 475-486.

GIZAW B. (1989) Geochemical investigation of the Aluto-Langano geothermal field, Ethiopian Rift Valley. M. Phil. dissertation (unpubl.), Univ. Leeds, U.K.

GIZAW B. (1993) Aluto-Langano geothermal field, Ethiopian Rift Valley: physical characteristics and the effects of gas on well performance. Geothermics 22, 101-116.

GLOVER, R.B. (1972) Chemical characteristics of water and steam discharges in the Rift Valley of Kenya. UNDP Tech. Rep.

Glover, R.B. (1976) Geochemical investigations in the Lakes District and Afar of Ethiopia. Rep. DSIR Chem. Div., Wairakei, N.Z.

GodFrey, B. and ARMANnSSON, H. (1995) The chemistry of waters in the Buranga and Kibiro geothermal fields, West Uganda. In: Water-Rock Interaction (eds Y.K. Kharaka, O.V. Chudaev), Balkema, pp 505-509.

HAUKWA C.B. (1986) Interpretation of well measurements for exploration areas and reservoir changes in Olkaria East field. KPLC Tech. Rep. 
KhaRAKa Y.K., MARINER R.H., Evans W.C. and KenNEDY B.M. (1992). Composition of gases from the Norris-Mammoth corridor, Yellowstone National Park, USA: Evidence for a magmatic source near Mammoth Hot Springs. In Water-Rock Interaction (Ed. Y.K. KHARAKA and A.S. MAEST), Balkema, pp 1303-1307.

LYON G.L. and HULSTON J.R. (1984). Carbon and hydrogen isotope composition of New Zealand geothermal gases. Geochim. Cosmochim. Acta 48, 1161-1171

Marty B., Appora I., Barrat J.A., Deniel C., Vellutini P. and Vidal P. (1993) He, Ar, Sr, Nd and $\mathrm{Pb}$ isotopes in volcanic rocks from Afar: Evidence for a primitive mantle component and constraints on magmatic sources. Geochem. J. 27, 219-228.

Motyka R.J., PoReda R.J. and JEFFREY A.W.A. (1989) Geochemistry, isotopic composition, and origin of fluids emanating from mud volcanoes in the Copper River basin, Alaska. Geochim. Cosmochim. Acta 53, 29-41.

MUNA Z.W. (1984) An attempt to build a reservoir model from the chemistry of well discharges in the Olkaria field. KPLC Tech. Rep

Pflumio C., Boulegue J. and Tiercelin J.J. (1994). Hydrothermal activity in the Northern Tanganyika Rift, East Africa. Chem. Geol. 116, 85-109.

SANJUAN B., MichaRD G. and MichaRD A. (1990). Origine des substances dissoutes dans les eaux des sources thermales et des forages de la region Asal-Ghoubbet (Republique de Djibouti). J. Volc. Geotherm. Res. 43, 333-352.

SIMONEIT B.R.T. (1994). Organic matter alteration and fluid migration in hydrothermal systems. In Geofluids: Origin, Migration and Evolution in Sedimentary Basins (ed. J. Parnell), Geol. Soc. Spec. Publ. No. 78, 261-274.

Sturchio N.C., Arehart G.B., Sultan M., Sano Y., AboKamar Y. and Sayed M. (1996). Composition and origin of thermal waters in the Gulf of Suez area, Egypt. Applied Geochemistry 11, 471-479.

Zan L., Gianelli G., PASSerini P, Troisi L. and HaGA O.A. (1990) Geothermal exploration in the Republic of Djibouti: thermal and geological data of the Hanle and Asal areas. Geothermics 19, 
561-582. 


\section{FIGURE CAPTIONS}

Fig 1 Map of the East African Rift System, with boxes showing the areas considered in this paper: a - Kenya, b - Ethiopia, c - Djibouti and d - Uganda. Enlargements of these areas are shown in Fig 2 a-d. The term 'Eastern Rift' used in the text refers to the Kenya and Ethiopian rifts plus southern Afar.

Fig 2 Enlargements of boxes from Fig 1: a - Kenya site map, b - Ethiopia site map, c - Djibouti site map, and d - Uganda site map. Site numbers in tables and text have prefix letters according to the country (D Djibouti, E - Ethiopia, K - Kenya, and U -Uganda).

Fig 3 Plots to characterise as molar ratios to methane the hydrocarbon contents of samples: ethane $\left(\mathrm{C}_{1} / \mathrm{C}_{2}\right)$, propane $\left(\mathrm{C}_{1} / \mathrm{C}_{3}\right)$, butane $\left(\mathrm{C}_{1} / \mathrm{C}_{4}\right)$, pentane $\left(\mathrm{C}_{1} / \mathrm{C}_{5}\right)$ and undifferentiated $\mathrm{C}_{6}\left(\mathrm{C}_{1} / \mathrm{C}_{6}\right)$. (a) geothermal wells, (b) fumaroles, (c) springs. $\square$ - Kenya, $O$ - Ethiopia, $\wedge$ - Djibouti and $\diamond$ - Uganda.

Fig 4 Plot of $\delta^{13} \mathrm{C}_{-} \mathrm{CO}_{2}$ versus $\delta^{13} \mathrm{C}-\mathrm{CH}_{4}$ for hydrothermal sites, identified by country and sample type. Manifestations of gas with $>90 \%$ air (circled) have depleted $\delta^{13} \mathrm{C}_{-} \mathrm{CO}_{2}$ compositions due to contamination, but their $\delta^{13} \mathrm{C}_{-} \mathrm{CH}_{4}$ compositions are little altered. Ugandan spring samples are from a thick sedimentary sequence, which has affected the $\mathrm{C}$ isotope systematics for both $\mathrm{CH}_{4}$ and $\mathrm{CO}_{2}$.

Fig 5 Ratios for $\mathrm{nC}_{4} / \mathrm{iC}_{4}, \mathrm{nC}_{5} / \mathrm{iC}_{5}$ and benzene/hexane in hydrothermal hydrocarbons (all sample types), showing a tendency for ratios to increase with rise in methane/ethane $\left(\mathrm{C}_{1} / \mathrm{C}_{2}\right)$ ratio.

Fig 6 Plot of ${ }^{3} \mathrm{He} /{ }^{4} \mathrm{He}$ as $\mathrm{R} / \mathrm{R}_{\mathrm{A}}$ versus methane/ethane $\left(\mathrm{C}_{1} / \mathrm{C}_{2}\right)$ ratio for Eastern Rift hydrothermal gases. Samples are divided into upper mantle ('MORB', Kenya) and lower mantle hotspot (Ethiopia and Djibouti) categories. He isotope data from CRAIG et al (1977) DARLING et al (1995) and DARLING (1996).

Fig 7 Plot of measured maximum (T max), $\mathrm{Na} / \mathrm{K}$ and quartz $\left(\mathrm{SiO}_{2}\right)$ solute temperatures $\left({ }^{\circ} \mathrm{C}\right)$ for individual geothermal wells in Kenya (OW, EW), Ethiopia (LA) and Djibouti (A). Based on data from MUNA (1985) and Kenya Power and Light Company records for Kenya, GIZAW (1989) for Ethiopia, and ZAN et al (1990) for Djibouti.

Fig 8 Plots of gas geothermometry temperature versus reservoir averaged solute temperature $\left(\mathrm{T}_{\mathrm{as}}\right)$ for geothermal wells in Kenya ( $\bullet$ ), Ethiopia $(\bullet)$ and Djibouti $(\boldsymbol{\Delta})$. Based on temperature data from Fig 7 , gas data from ARNORSSON et al (1990), DARLING and TALBOT (1991) and GIZAW (1989), and the gas geothermometers of DARLING (this issue) $\left(\mathrm{C}_{1} / \mathrm{C}_{2}\right)$, D'AMORE and PANICHI (1980) (D-P), and ARNORSSON and GUNNLAUGSSON (1985) for the remainder.

Fig 9 Map showing the area around the Ololbutot fault zone of the Olkaria geothermal area, Kenya (refer to Fig 2a for general location). $2 \mathrm{~km}$ UTM grid squares are shown. Well (OW-) and fumarole (OF-) identifiers are shown, together with temperatures (in bold) calculated by averaged solute geothermometry for the wells, and the methane/ethane $\left(\mathrm{C}_{1} / \mathrm{C}_{2}\right)$ geothermometer for the fumaroles.

Fig 10 Map of the Aluto-Langano geothermal area, Ethiopia (refer to Fig $2 b$ for general location). Well (LA-) and fumarole and spring (name) identifiers are shown, together with temperatures in ${ }^{\circ} \mathrm{C}$ calculated from averaged solute geothermometry for the wells and spring, and the $\mathrm{C}_{1} / \mathrm{C}_{2}$ geothermometer for the fumaroles. 
Fig 11 Histograms for various gas geothermometers applied to fumaroles of the Eastern Rift (Kenya, Ethiopia and Djibouti). Black and white areas represent cumulatively wellfield and non-wellfield fumaroles respectively. Based on data from DARLING and TALBOT (1991), DARLING et al (1995), DUNKLEY et al (1993) and GLOVER $(1972,1976)$. Geothermometers as used for Fig 8, but note that where two versions of the Arnorsson and Gunnlaugsson geothermometers exist, both have been used because of uncertainties about subsurface conditions.

Fig 12 Plot of reservoir chalcedony geothermometer temperature $\left({ }^{\circ} \mathrm{C}\right)$ versus methane/ethane $\left(\mathrm{C}_{1} / \mathrm{C}_{2}\right)$ ratio for low-enthalpy hot spring samples from Kenya, Ethiopia and Djibouti ('EARS'). Solute data from ALLEN et al (1989), Craig et al (1977), DARLING and TALBOT (1991) and DUNKLEY et al (1993). Analyses from similar systems at Colli Albani in Italy (GIGGENBACH et al, 1988), Mammoth, Wyoming (KHARAKA et al, 1992), Copper River, Alaska (MOTYKA et al, 1989) and the E coast of the Gulf of Suez, Egypt (STURCHIO et al, 1996) are also shown. 


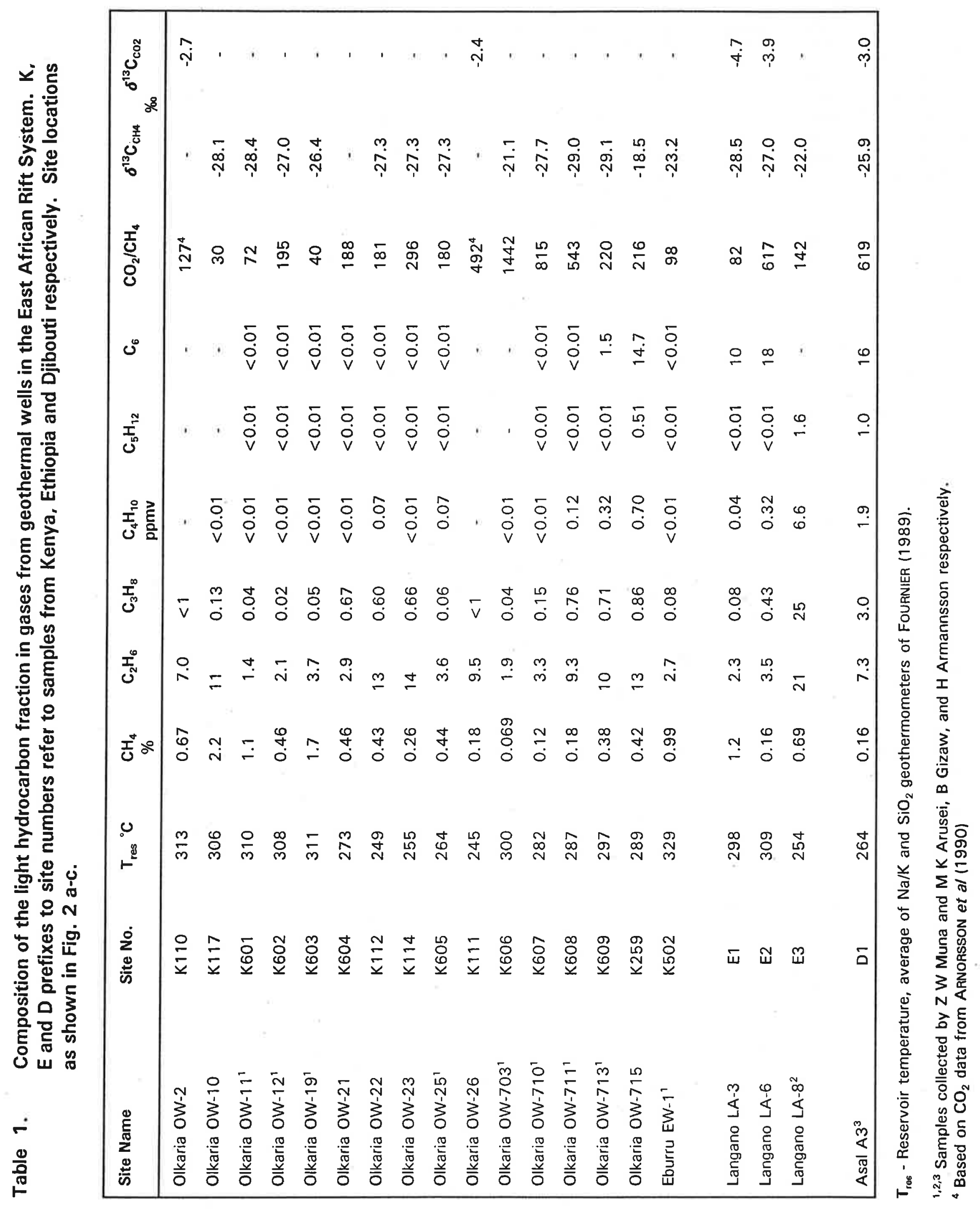


Table 2. Composition of light hydrocarbons in geothermal gases from predominantly fumarolic sources in the East African Rift System. $K, E$ and $D$ prefixes to site numbers refer to samples from Kenya, Ethiopia and Dijbouti respectively. Sample locations as shown in Fig. 2 a-c.

\begin{tabular}{|c|c|c|c|c|c|c|c|c|c|c|c|c|}
\hline Site Name & Site No. & $\begin{array}{l}\text { Sampling } \\
\text { Temp C }\end{array}$ & $\mathrm{CH}_{\%}$ & $\mathrm{C}_{2} \mathrm{H}_{6}$ & $\mathrm{C}_{\mathrm{j}} \mathrm{H}_{\mathrm{g}}$ & $\begin{array}{l}\mathrm{C}_{4} \mathrm{H}_{10} \\
\text { ppmv }\end{array}$ & $\mathrm{C}_{5} \mathrm{H}_{12}$ & $c_{6}$ & $\mathrm{CO}_{2} / \mathrm{CH}_{4}$ & $\delta^{13} C_{\mathrm{cH}+4}$ & $x_{0}{ }^{\circ}$ & $\delta^{13} C_{\mathrm{CO} 2}$ \\
\hline Suswa F-7 & K504 & 94 & 0.45 & 0.68 & $<1$ & . & - & - & 55 & - & & - \\
\hline Suswa F-12 & $\mathrm{K} 258$ & 94 & 0.087 & 0.40 & 0.1 & 0.22 & $<0.1$ & $<0.1$ & 190 & -25.0 & & -3.0 \\
\hline Suswa F-28' & K501 & 92 & 1.4 & 3.4 & $<1$ & - & - & - & 70 & - & & -3.7 \\
\hline Carbacid $\mathrm{CO}_{2}{ }^{2}$ & $K 237$ & $a m b$ & 1.2 & 190 & 58 & 24 & 8.9 & 3.9 & 79 & -20.5 & & -2.4 \\
\hline Longonot $\mathrm{F}-23$ & $\mathrm{~K} 128$ & 90 & 0.75 & 1 & $<1$ & - & . & . & 103 & - & & -4.0 \\
\hline Mt Marg. F-27' & $k 29$ & 85 & 0.18 & 1 & $<1$ & - & - & - & 529 & - & & -1.7 \\
\hline Domes F-15 & K127 & 92 & 0.13 & 2.5 & $<1$ & - & - & - & 134 & $\cdot$ & & -3.0 \\
\hline Akira $\mathrm{H}-1^{1,2}$ & K31 & 95 & 0.77 & 2.9 & $<1$ & - & - & - & 129 & . & & -2.1 \\
\hline Olkaria OF 1 & $\mathrm{~K} 261$ & 93 & 0.61 & 18 & 10 & 1.7 & 1.6 & 54 & 157 & -28.8 & & -3.4 \\
\hline Olkaria OF4 & $\mathrm{K} 262$ & 95 & 0.15 & 5.5 & $<0.1$ & $<0.1$ & 0.4 & 30 & 156 & -27.2 & & -5.6 \\
\hline Olkaria OF 13 & $\mathrm{~K} 263$ & 95 & 0.49 & 13 & 6 & $<0.1$ & $<0.1$ & $<0.1$ & 169 & -26.5 & & -4.0 \\
\hline Olkaria OF14 & $K 264$ & 94 & 0.38 & 74 & 1.1 & $<0.1$ & $<0.1$ & $<0.1$ & 222 & -26.0 & & -3.2 \\
\hline Olkaria OF 15 & $K 265$ & 91 & 0.24 & 5.4 & $<0.1$ & 0.9 & 0.2 & 99 & 287 & -26.7 & & -4.5 \\
\hline Olkaria OF16 & $\mathrm{K} 266$ & 96 & 1.60 & 5.5 & $<0.1$ & 7.6 & 0.2 & 562 & 56 & -26.7 & & -5.0 \\
\hline Olkaria OF20 & $\mathrm{K} 267$ & 78 & 0.034 & 0.06 & $<0.1$ & $<0.1$ & $<0.1$ & $<0.1$ & 2770 & -24.5 & & -3.6 \\
\hline Olkaria OFW & K123 & . & 0.37 & 11 & $<1$ & • & - & • & 201 & • & & -2.8 \\
\hline Eburru EF2 & K119 & 92 & 4.6 & 5.0 & $<1$ & - & • & . & 17 & $\because$ & & -2.3 \\
\hline Arus AR1 & $K 257$ & 95 & 0.35 & 6.4 & 1.2 & 0.4 & $<0.1$ & 24 & 284 & -28.1 & & -4.3 \\
\hline Of Kokwe OK1 & K152 & 96 & 0.32 & 20 & 4 & $<1$ & . & . & 278 & -18.3 & & -3.5 \\
\hline Korosi KR12 & K154 & 96 & 0.21 & 8 & 3 & $<1$ & . & . & 203 & $\cdot$ & & -4.3 \\
\hline Korosi KR18 & $\mathrm{K} 156$ & 96 & 1.5 & 340 & 130 & 43 & - & . & 64 & -24.5 & & -3.9 \\
\hline Korosi KR19 & K157 & 96 & 1.3 & 290 & 130 & 26 & $\cdot$ & $\cdot$ & 75 & -23.4 & & -3.9 \\
\hline Korosi KR23 & $\mathrm{K} 158$ & 96 & 0.015 & 9 & 0.8 & 0.2 & $<0.1$ & - & 1090 & -19.7 & & -6.2 \\
\hline Korosi KR34 & K162 & 92 & 0.44 & 98 & 16 & 17 & 12 & 21 & 192 & -29.6 & & -4.6 \\
\hline Paka PK1 & K163 & 96 & 1.5 & 1.0 & $<0.1$ & $<0.1$ & - & - & 55 & -24.9 & & -2.9 \\
\hline Paka PK4 & K166 & 95 & 1.3 & 1.0 & $<0.1$ & $<0.9$ & - & $\cdot$ & 71 & -27.8 & & -3.4 \\
\hline Paka PK7 & $\mathrm{K} 168$ & 94 & 0.85 & 38 & 14 & 6 & - & - & 79 & -22.2 & & -2.7 \\
\hline Silali SL7 & $\mathrm{K} 219$ & 95 & 0.25 & 0.7 & $<0.1$ & $<0.1$ & - & - & 391 & -23.0 & & -3.8 \\
\hline Slilai SL11 & $\mathrm{K} 220$ & 94 & 0.48 & 18 & 4 & $<0.1$ & • & $\cdot$ & 108 & -24.3 & & - \\
\hline Silali SL14 & $\mathrm{K} 221$ & 96 & 0.25 & 0.6 & 0.1 & $<0.1$ & $\bullet$ & $\cdot$ & 393 & -24.3 & & -3.7 \\
\hline Silali SL15 & $\mathrm{K} 2.22$ & 97 & 0.24 & 1.0 & 0.1 & $<0.1$ & • & - & 408 & -25.0 & & -3.9 \\
\hline Silali SL16 & $\mathrm{K} 223$ & 96 & 0.026 & 0.3 & 0.2 & $<0.1$ & - & $\cdot$ & 1000 & -23.5 & & -4.7 \\
\hline Silali SL19 & $\mathrm{K} 224$ & 96 & 1.1 & 0.5 & $<0.1$ & $<0.1$ & • & - & 70 & - & . & -4.6 \\
\hline Silali SL22 & K225 & 92 & 0.17 & 0.6 & 0.1 & $<0.1$ & . & • & 408 & -21.7 & & -3.6 \\
\hline Emuruang. EM9 & $\mathrm{K} 228$ & 95 & 0.64 & 20 & 2.0 & $<0.1$ & . & - & 45 & -20.7 & & -4.7 \\
\hline Emuruang. EM20 & $\mathrm{K} 232$ & 96 & 0.51 & 0.1 & $<0.1$ & $<0.1$ & - & $\cdot$ & 114 & -22.5 & & -4.0 \\
\hline Barrier BR4 & $\mathrm{K} 249$ & 94 & 0.023 & 0.84 & $<0.1$ & $<0.1$ & $<0.1$ & 32 & 301 & -24.4 & & -5.7 \\
\hline Barrier BR5 & $\mathrm{K} 248$ & 93 & 0.014 & 0.23 & $<0.1$ & $<0.1$ & $<0.1$ & 12 & 257 & -26.0 & & -9.8 \\
\hline Barrier BR11 & $K 235$ & 96 & 0.044 & 0.1 & $<0.1$ & $<0.1$ & - & - & 389 & -26.3 & & -3.3 \\
\hline Barrier BR18 & $K 250$ & 94 & 0.020 & 6.3 & $<0.1$ & $<0.1$ & $<0.1$ & $<0.1$ & 441 & -25.8 & & -6.0 \\
\hline Barrier BR29 & $\mathrm{K} 251$ & 93 & 0.064 & 1.2 & 0.17 & $<0.1$ & $<0.1$ & $<0.1$ & 79 & -26.6 & & -4.0 \\
\hline Central Is $\mathrm{Cl} 1$ & $\mathrm{~K} 254$ & 97 & 0.90 & 45 & 11 & 4.9 & 2.8 & 140 & 104 & -32.2 & . & -4.3 \\
\hline Central is $\mathrm{Cl} 2$ & $K 255$ & 97 & 0.89 & 46 & 9.4 & 3.7 & 3.7 & 134 & 97 & -30.9 & & -3.8 \\
\hline North Is NI1 & $K 252$ & 96 & 0.47 & 29 & 5.5 & 0.7 & 0.7 & 75 & 84 & -28.2 & & -5.2 \\
\hline North Is N/2 & $K 253$ & 96 & 1.1 & 80 & 10 & 1.1 & 0.7 & 35 & 79 & -28.4 & & -5.4 \\
\hline Corb. Chebicha & E7 & 80 & 0.0065 & 0.09 & 1.9 & $<0.01$ & $<0.01$ & $<0.01$ & 141 & -29.9 & & -8.7 \\
\hline Corb. Danshe & E8 & 90 & 0.032 & 1.3 & 0.11 & 0.05 & $<0.01$ & $<0.01$ & 197 & -30.7 & & -7.1 \\
\hline Corbetti Koka & E9 & 94 & 0.17 & 140 & 58 & 28 & 10 & 22 & 587 & .28 .6 & & -3.5 \\
\hline Aluto Bobessa & E4 & - & 0.14 & 6.0 & 0.16 & $<0.01$ & $<0.01$ & $<0.01$ & 348 & -25.7 & & -4.1 \\
\hline Aluto Gebiba & E5 & 93 & 0.32 & 11 & 3.3 & 3.2 & 1.7 & 5.5 & 311 & -25.7 & & -4.1 \\
\hline Aluto Auto & E6 & 90 & 0.017 & 1.8 & 0.47 & $<0.01$ & $<0.01$ & $<0.01$ & 182 & . & & -7.5 \\
\hline Gedemsa Boku & E10 & 73 & 0.016 & 0.11 & $<0.1$ & $<0.1$ & $<0.1$ & $<0.1$ & 144 & -24.0 & & -10.7 \\
\hline Garrabays & 04 & - & 0.0077 & 0.24 & 0.02 & $<0.01$ & $<0.01$ & $<0.01$ & 43 & -31.1 & & -9.8 \\
\hline Asal & $\mathrm{D} 2$ & - & 0.0009 & 0.02 & $<0.01$ & $<0.01$ & $<0.01$ & $<0.01$ & 10460 & -32.1 & & -5.7 \\
\hline N. Ghoubet & D3 & . & 0.023 & 1.6 & 0.14 & 0.43 & $<0.01$ & $<0.01$ & 717 & -17.0 & & -3.1 \\
\hline
\end{tabular}

' sample collected by $\mathrm{H}$ Armannsson

${ }^{2} \mathrm{dry}$ borehole - all other samples from fumaroles 


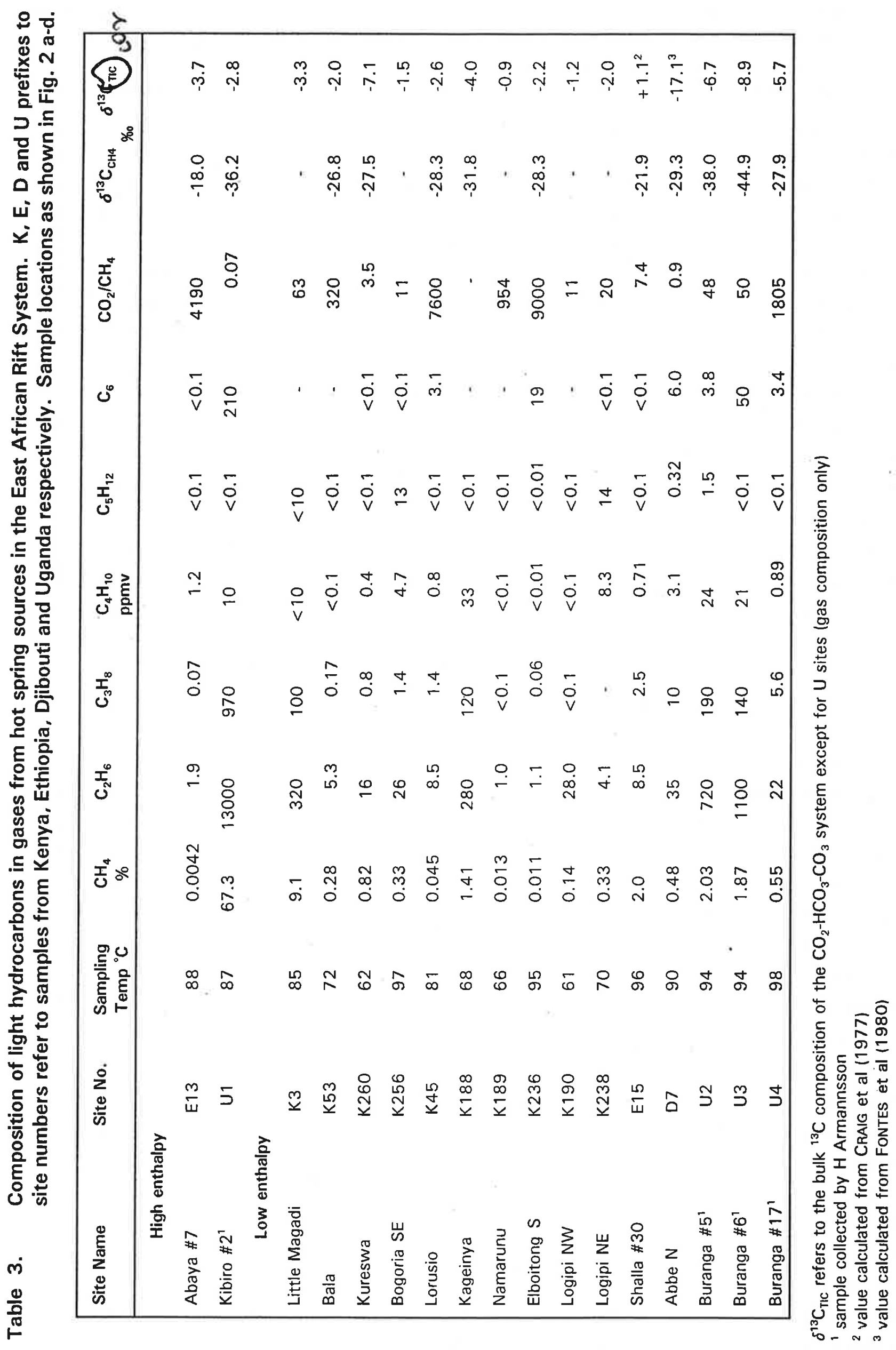


Fable 4. Isomeric ratios for butane and pentane and ratios of benzene to hexane for hydrothermal gases from various sources in the East African Rift System. The signs ' $>$ ' and ' $<$ ' denote cases where hexane and benzene respectively are below detection limit.

\begin{tabular}{|c|c|c|c|c|}
\hline Site Name & Site No. & $\mathrm{nC}_{4} / \mathrm{iC}_{4}$ & $\mathrm{nC}_{5} / \mathrm{iC}_{5}$ & ben/hex \\
\hline \multicolumn{5}{|l|}{ FUMAROLES } \\
\hline Suswa F-12 & K258 & - & $\cdots$ & $<0.003$ \\
\hline Carbacid Co. & K237 & 2.0 & 0.85 & 0.50 \\
\hline Olkaria OF1 & K261 & 1.5 & - & 0.32 \\
\hline Olkaria OF4 & K262 & - & - & $>300$ \\
\hline Olkaria OF15 & K265 & 10 & 3.2 & $>990$ \\
\hline Olkaria OF 16 & K266 & - & - & $>5600$ \\
\hline Arus AR1 & K257 & 13 & 6.3 & 2.1 \\
\hline Korosi KR18 & K156 & 2.6 & - &.- \\
\hline Korosi KR19 & K157 & 2.5 & - & - \\
\hline Korosi KR23 & K158 & 1.0 & - & - \\
\hline Korosi KR34 & K162 & 3.3 & 2.3 & 1.5 \\
\hline Paka PK7 & K168 & 1.1 & - & - \\
\hline Barrier KK2 & K248 & - & - & $<0.009$ \\
\hline Barrier KK3 & K249 & - & - & $<0.003$ \\
\hline Central Is $\mathrm{Cl} 1$ & K254 & 4.7 & 3.1 & 4.6 \\
\hline Central Is $\mathrm{Cl} 2$ & K255 & 4.5 & 2.1 & 3.3 \\
\hline North Is NI2 & K253 & 3.7 & 2.0 & 3.2 \\
\hline Corbetti Koka & E9 & 2.6 & 10 & 0.46 \\
\hline Aluto Gebiba & E5 & 1.3 & 24 & 5.4 \\
\hline Nord Ghoubet & D3 & 1.8 & . & - \\
\hline \multicolumn{5}{|c|}{ GEOTHERMAL WELLS } \\
\hline Olkaria OW-713 & K608 & - & - & $>15$ \\
\hline Olkaria OW-715 & K259 & - & 2.0 & $>7500$ \\
\hline Langano LA-3 & E1 & 3.0 & - & 1.8 \\
\hline Langano LA-6 & E2 & - & - & 15 \\
\hline Langano LA-8 & E3 & 0.78 & 0.88 & - \\
\hline Asal A3 & D1 & 0.86 & 1.5 & 19 \\
\hline \multicolumn{5}{|l|}{ SPRINGS } \\
\hline Bogoria SE & K260 & - & 0.36 & - \\
\hline Lorusio & K45 & 2.9 & - & $>31$ \\
\hline Kageinya & K188 & 0.57 & - & - \\
\hline Elboitong $S$ & K236 & - & - & 0.19 \\
\hline Abaya \#7 & E13 & 1.0 & - & - \\
\hline Shalla \#30 & E15 & 2.2 & - & - \\
\hline Abbe $N$ & D7 & 0.55 & 1.0 & $>60$ \\
\hline Kibiro \#2 & U1 & 4.7 & - & $>200$ \\
\hline Buranga \#5 & U2 & 2.0 & 0.27 & $>4$ \\
\hline Buranga \#6 & U3 & 1.5 & - & $>50$ \\
\hline Buranga \#7 & U4 & 2.0 & - & $>4$ \\
\hline
\end{tabular}




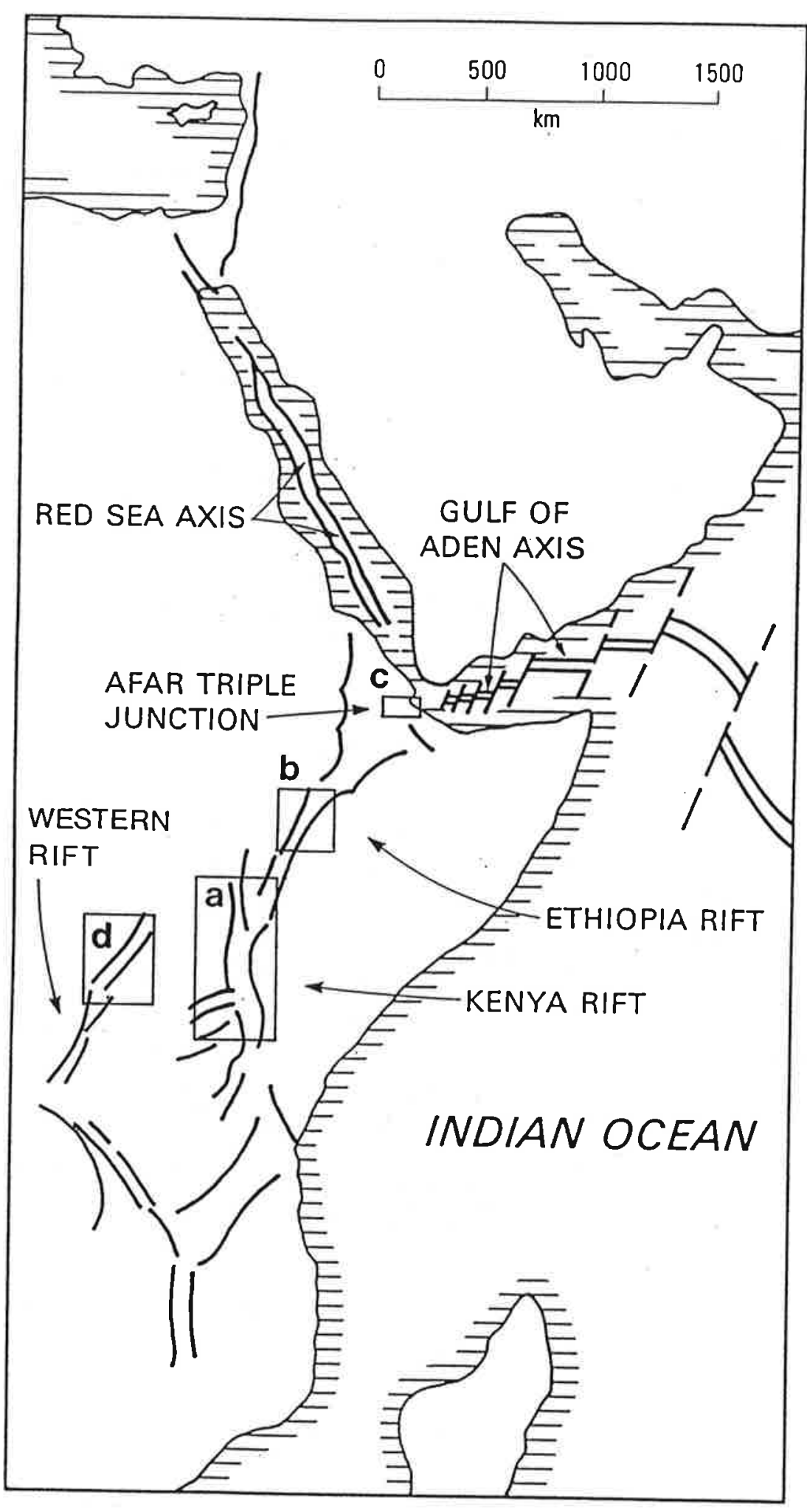

Fig I 


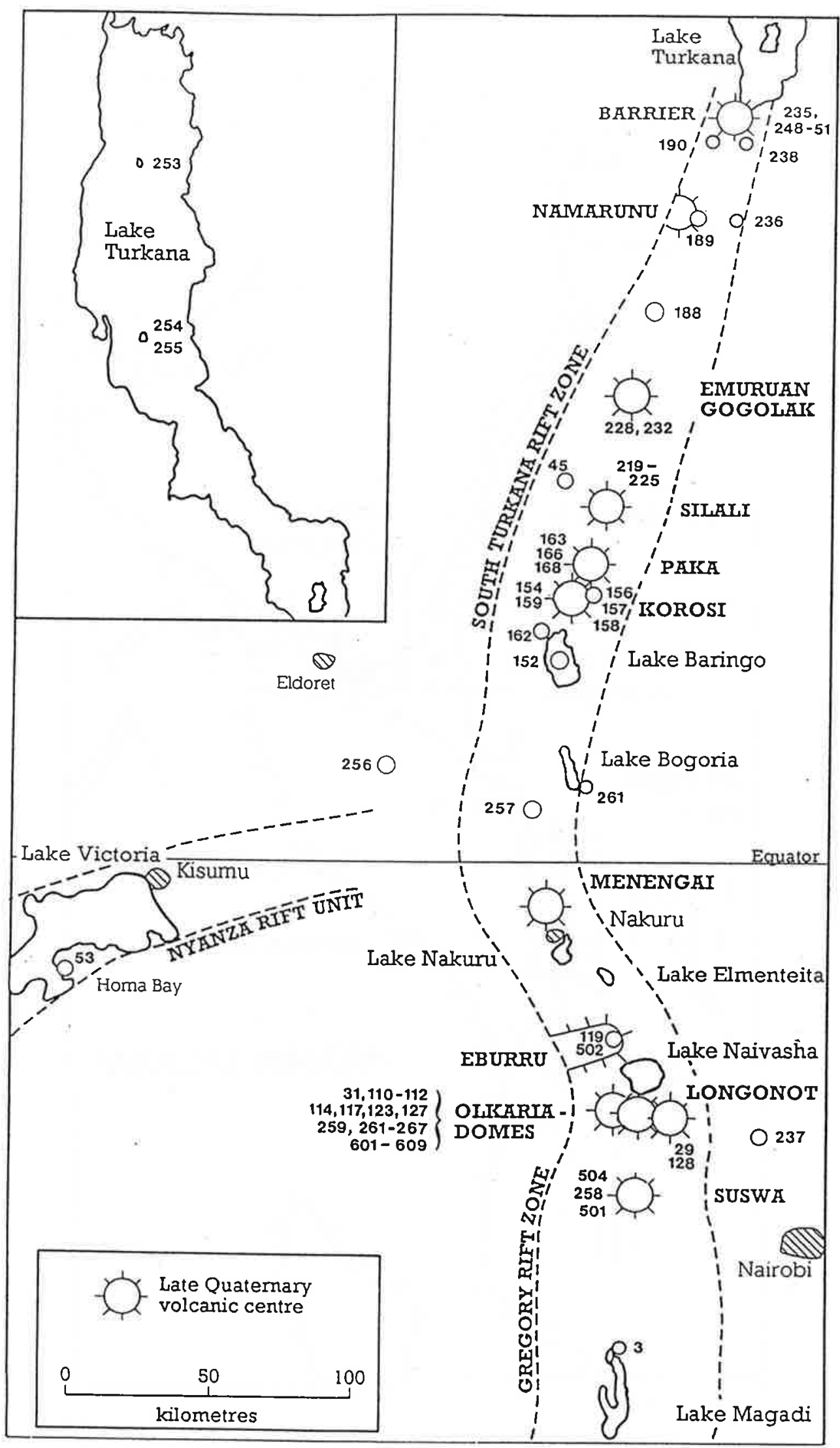

Wor DARLING

AG 95-163

FlG $2 a$ 

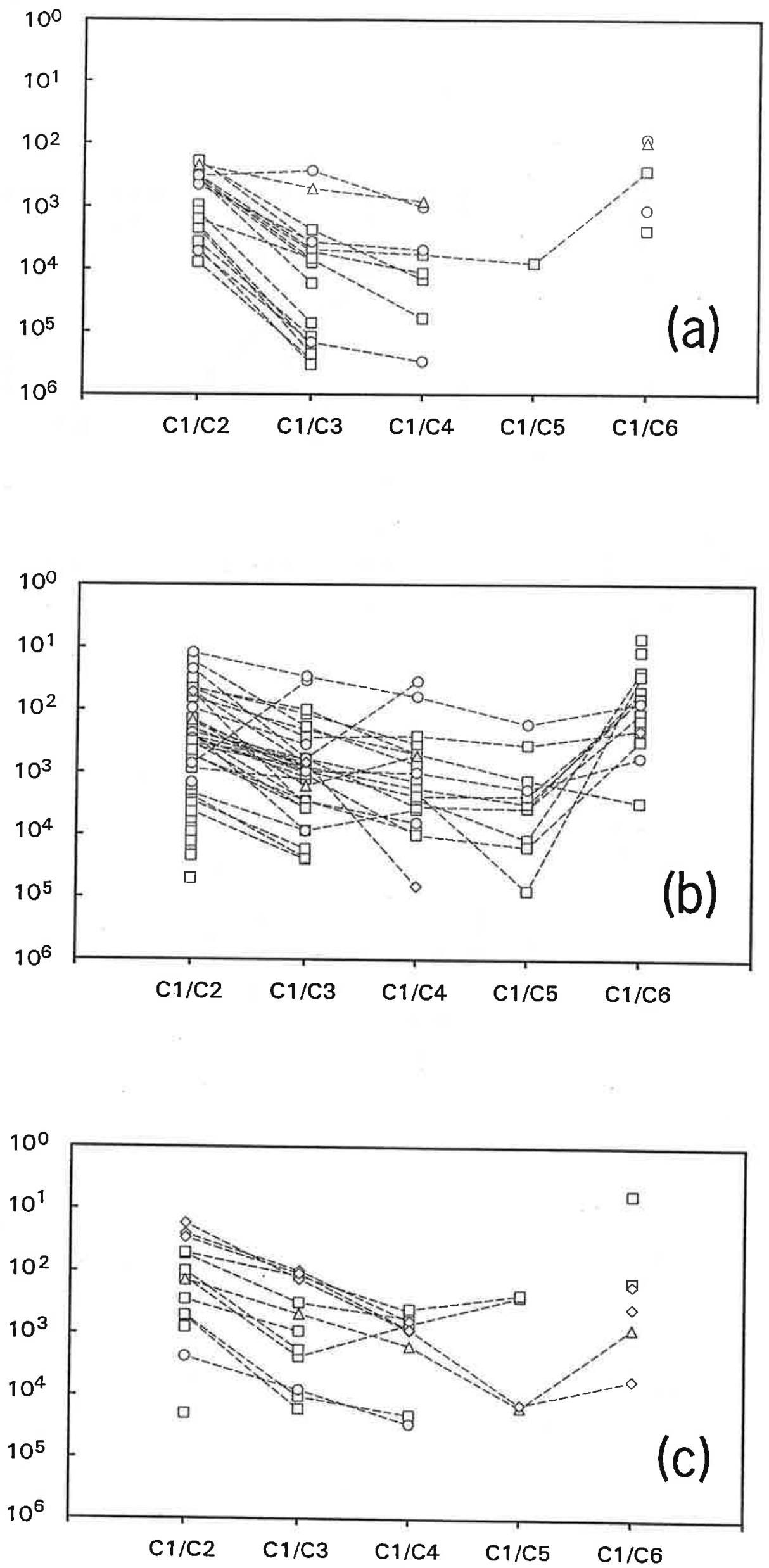

Fig 3 

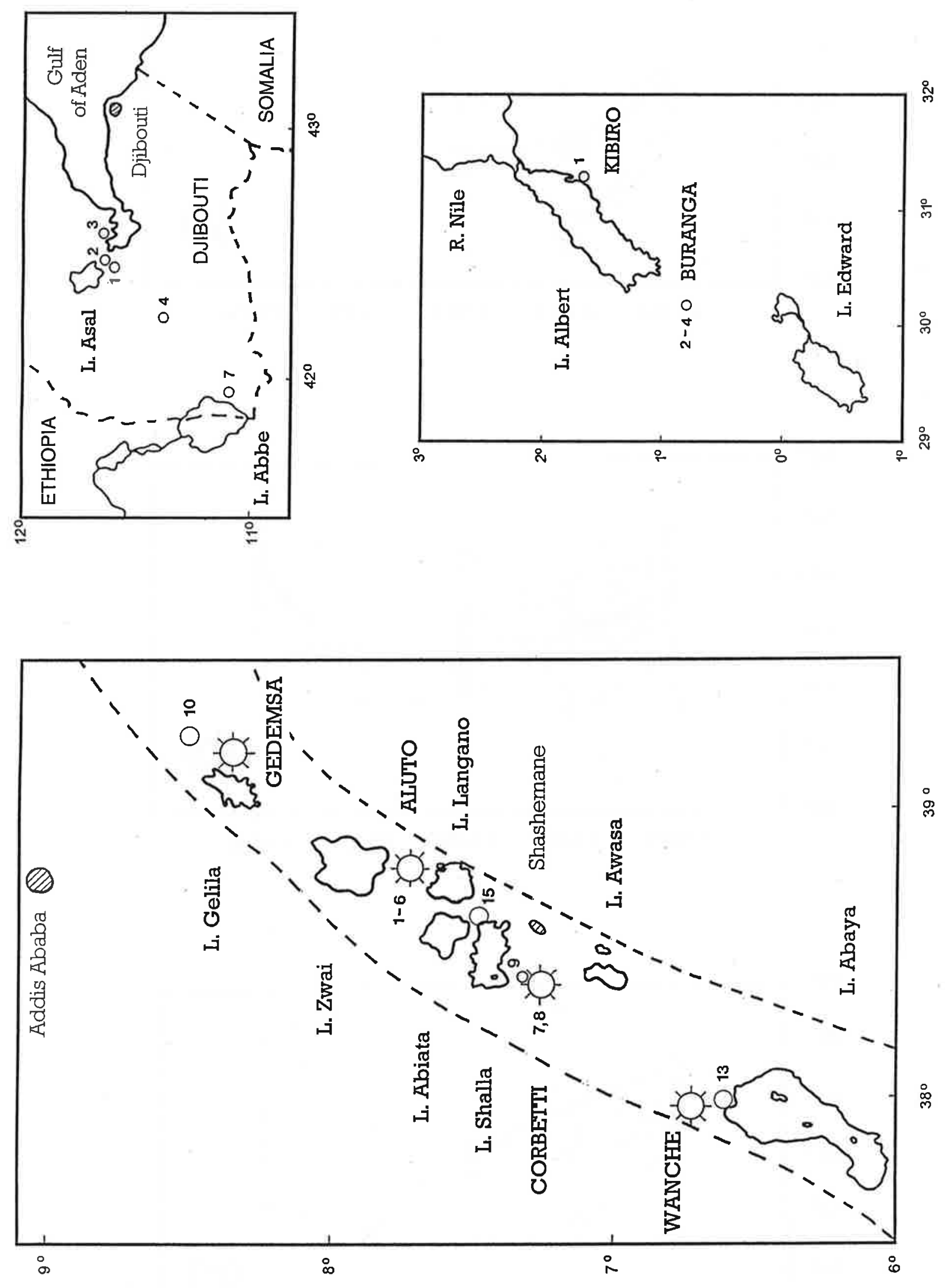

Fig $2 b-d$ 


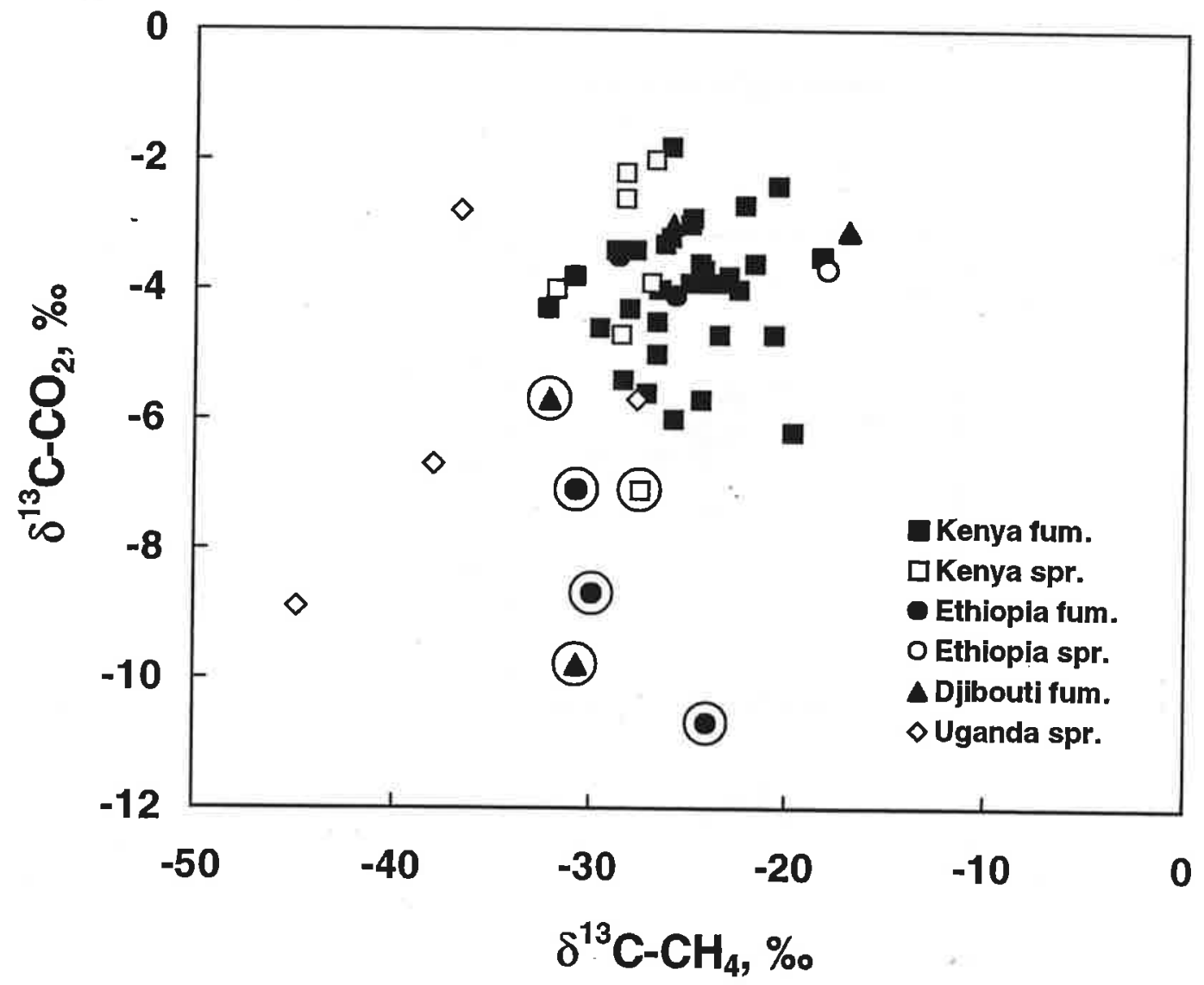

Fig 4 

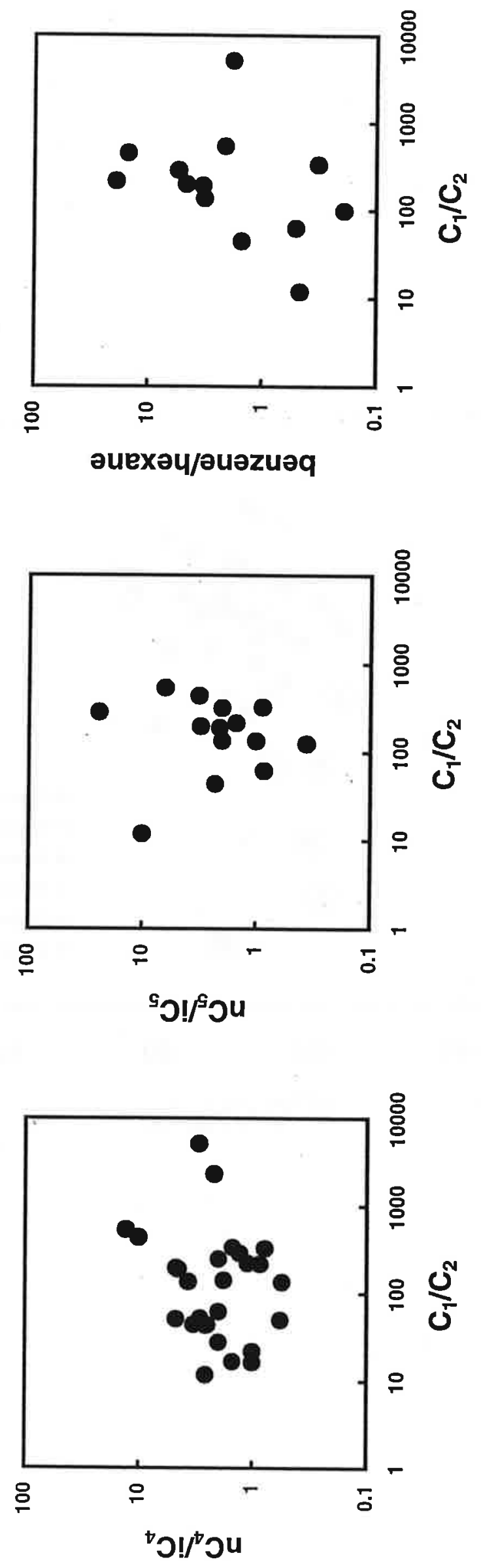


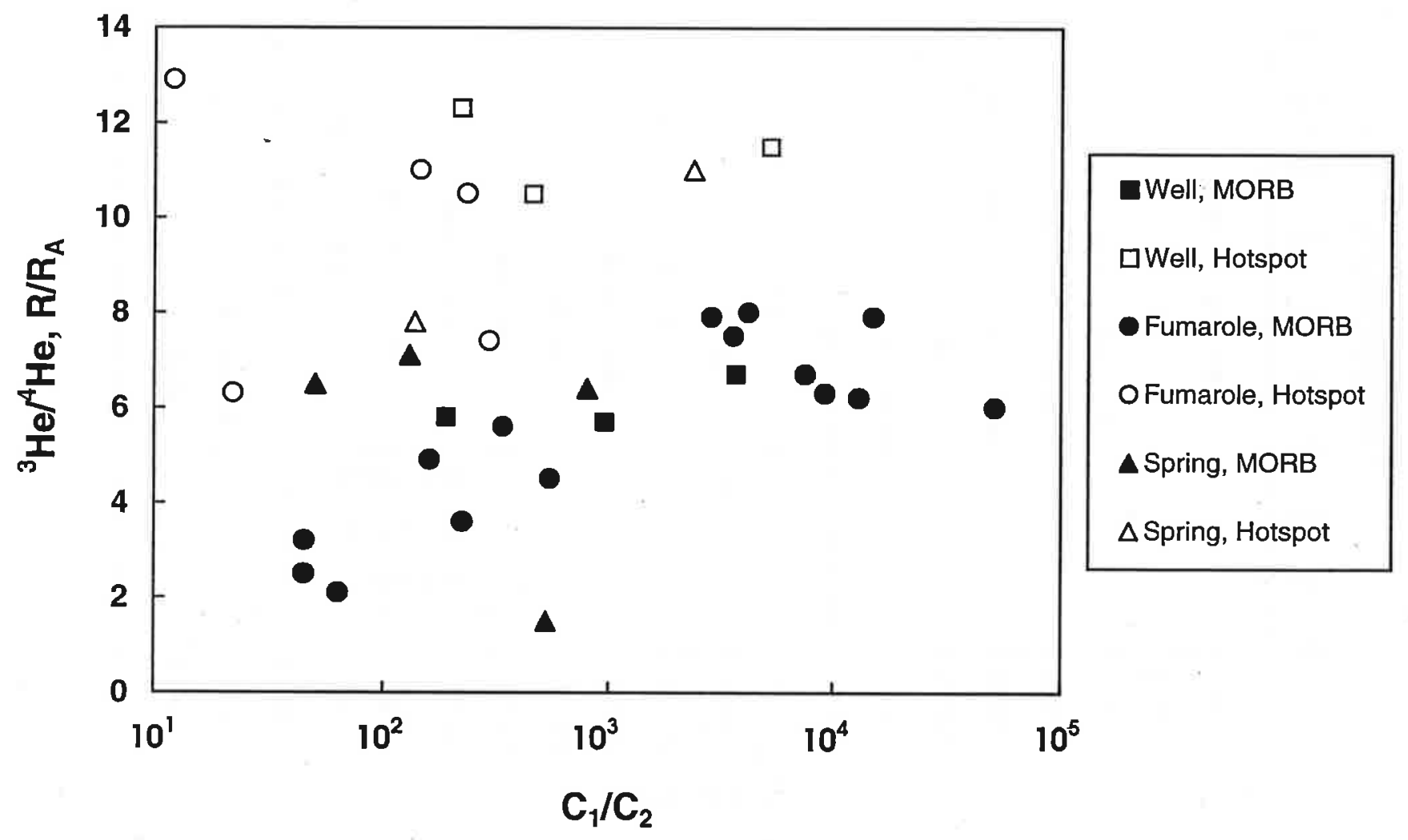

Fig 6 


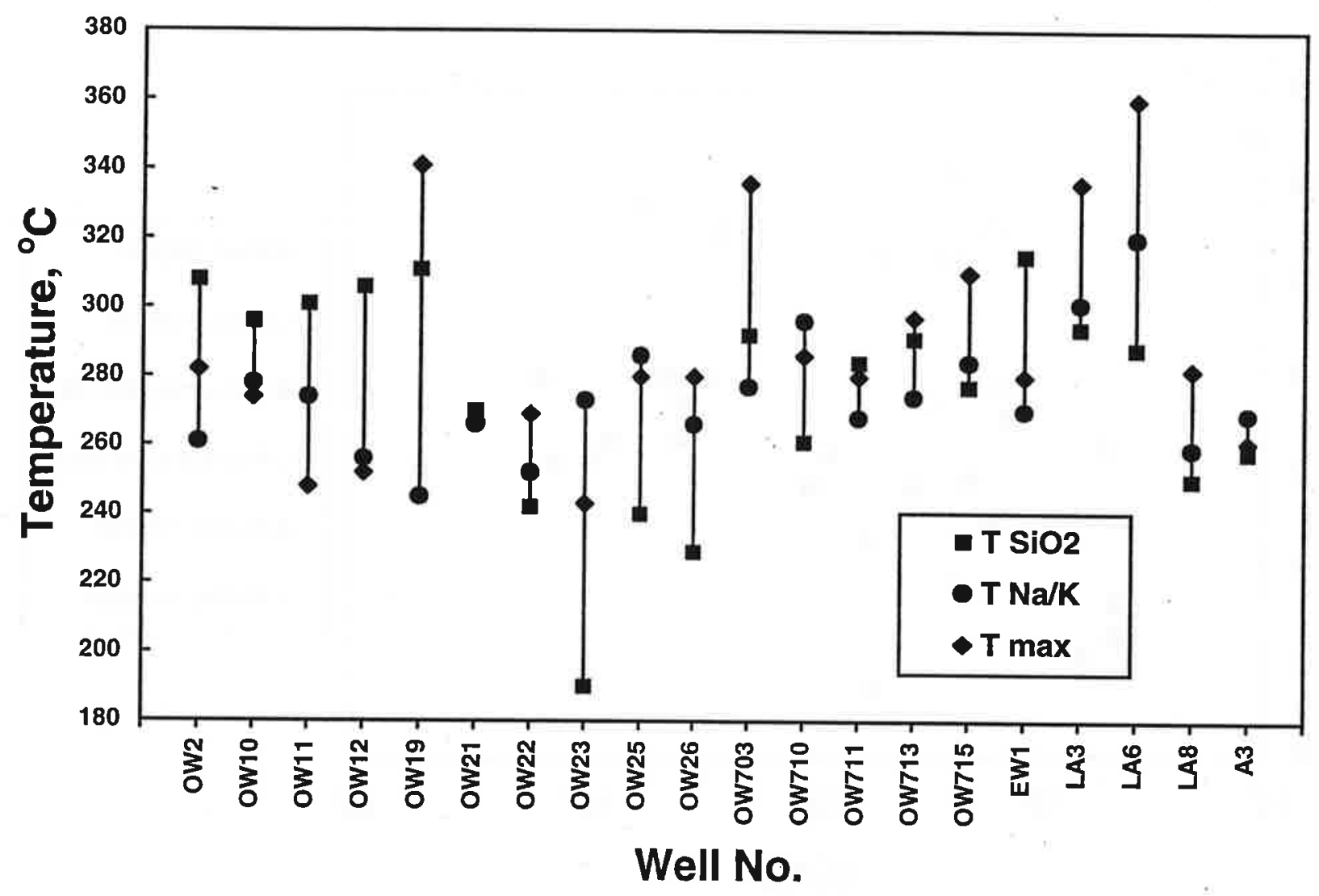

Fig 7 

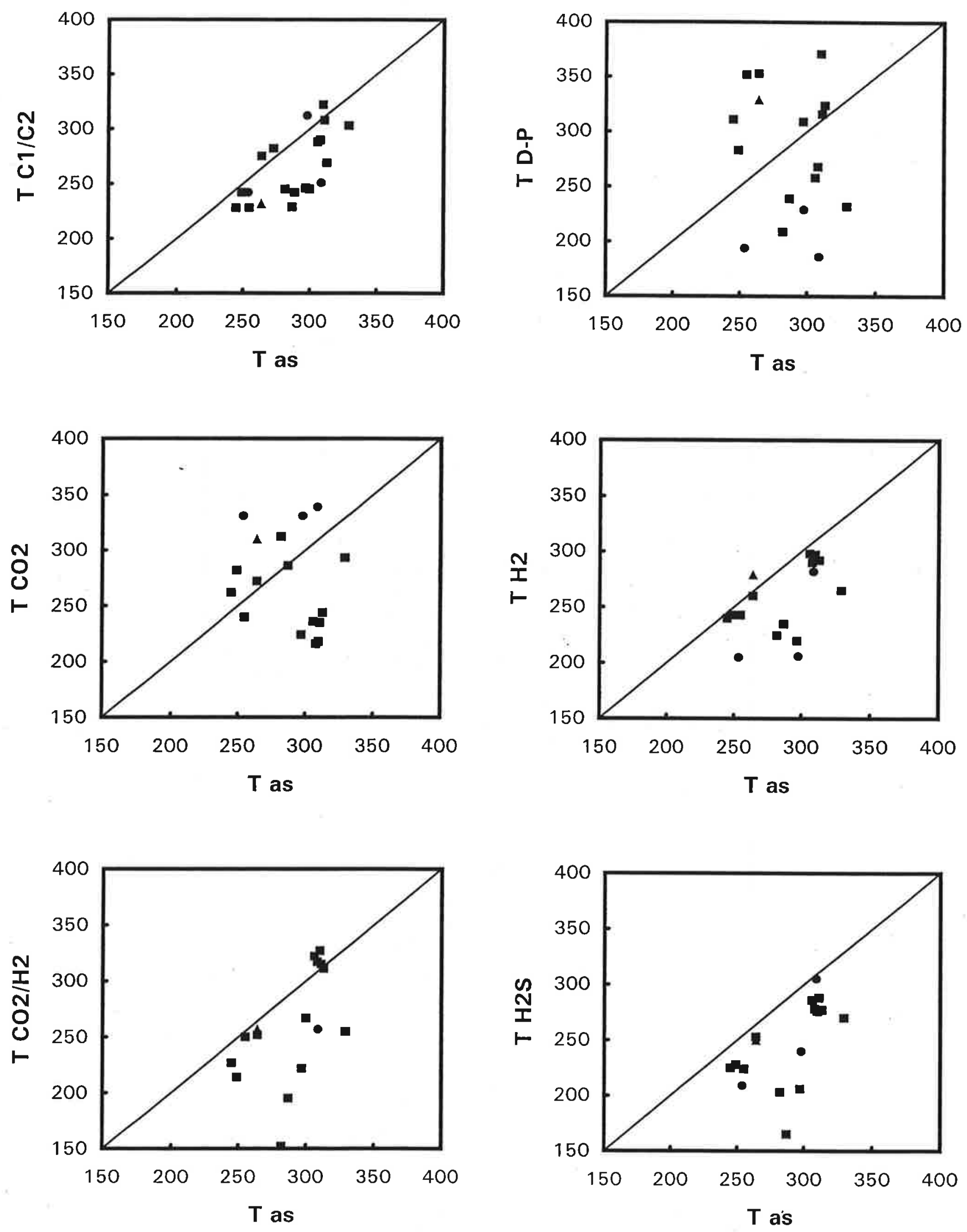

Fig 8 


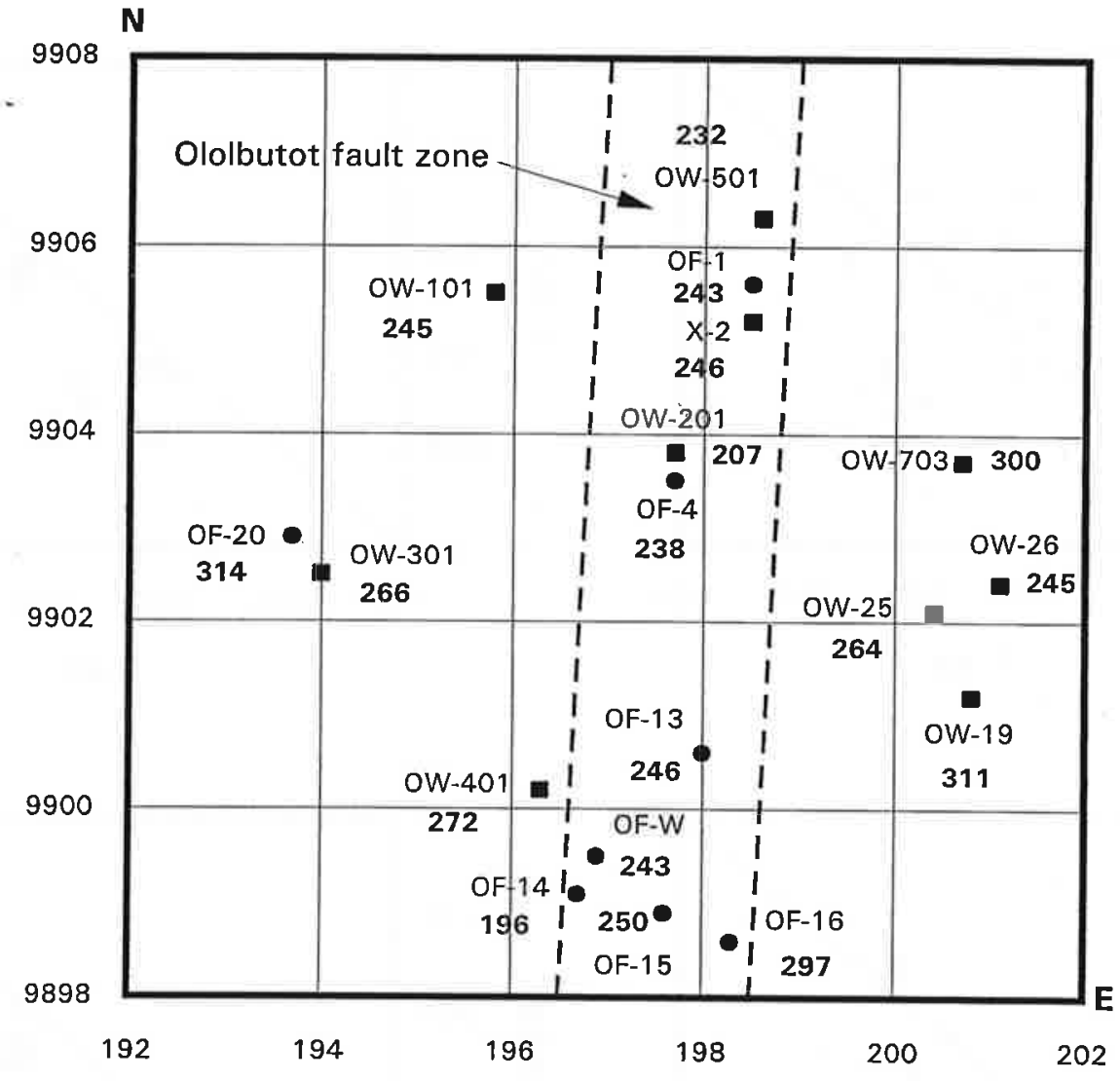

Fig 9 


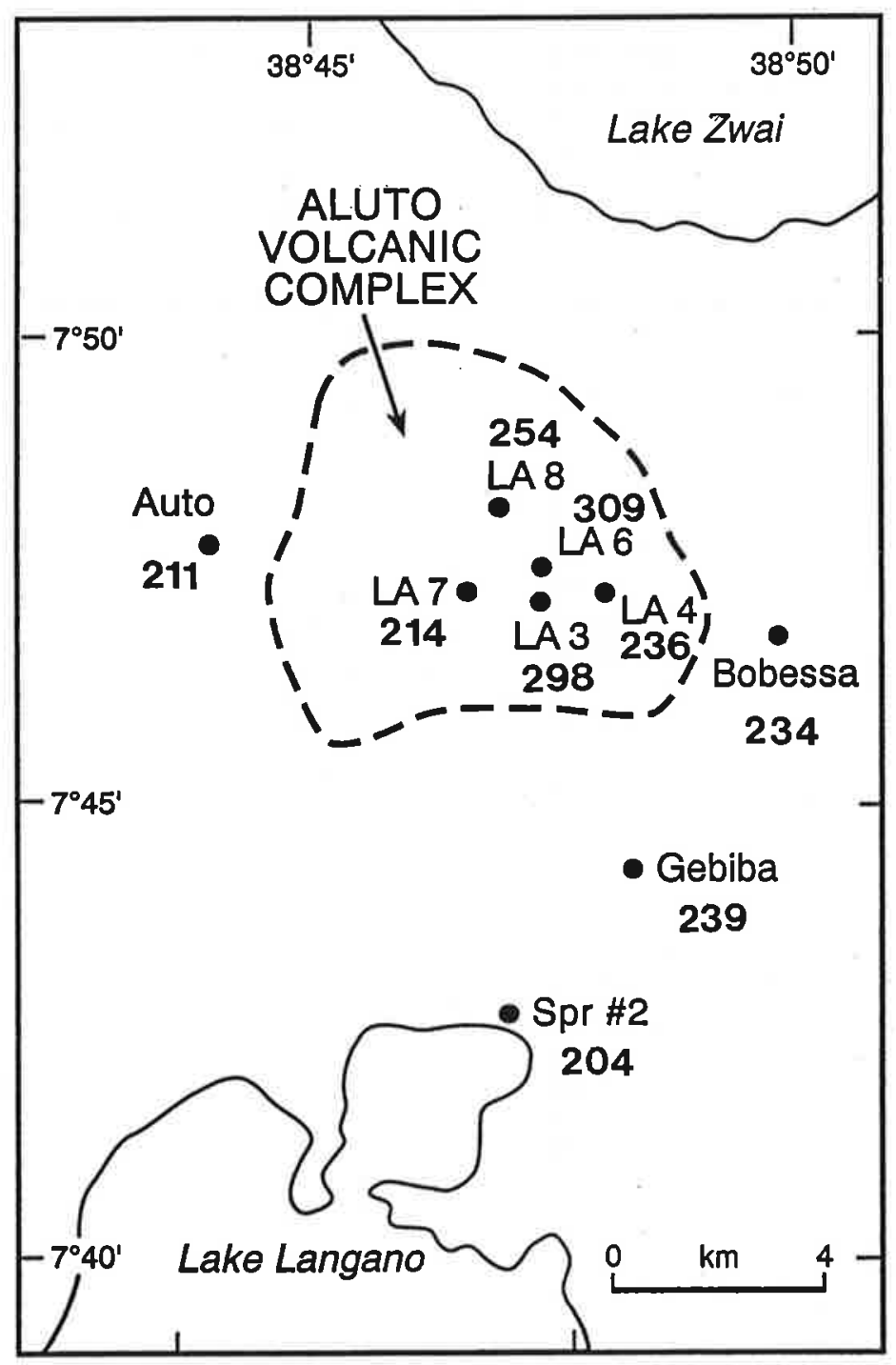

Fig 10 

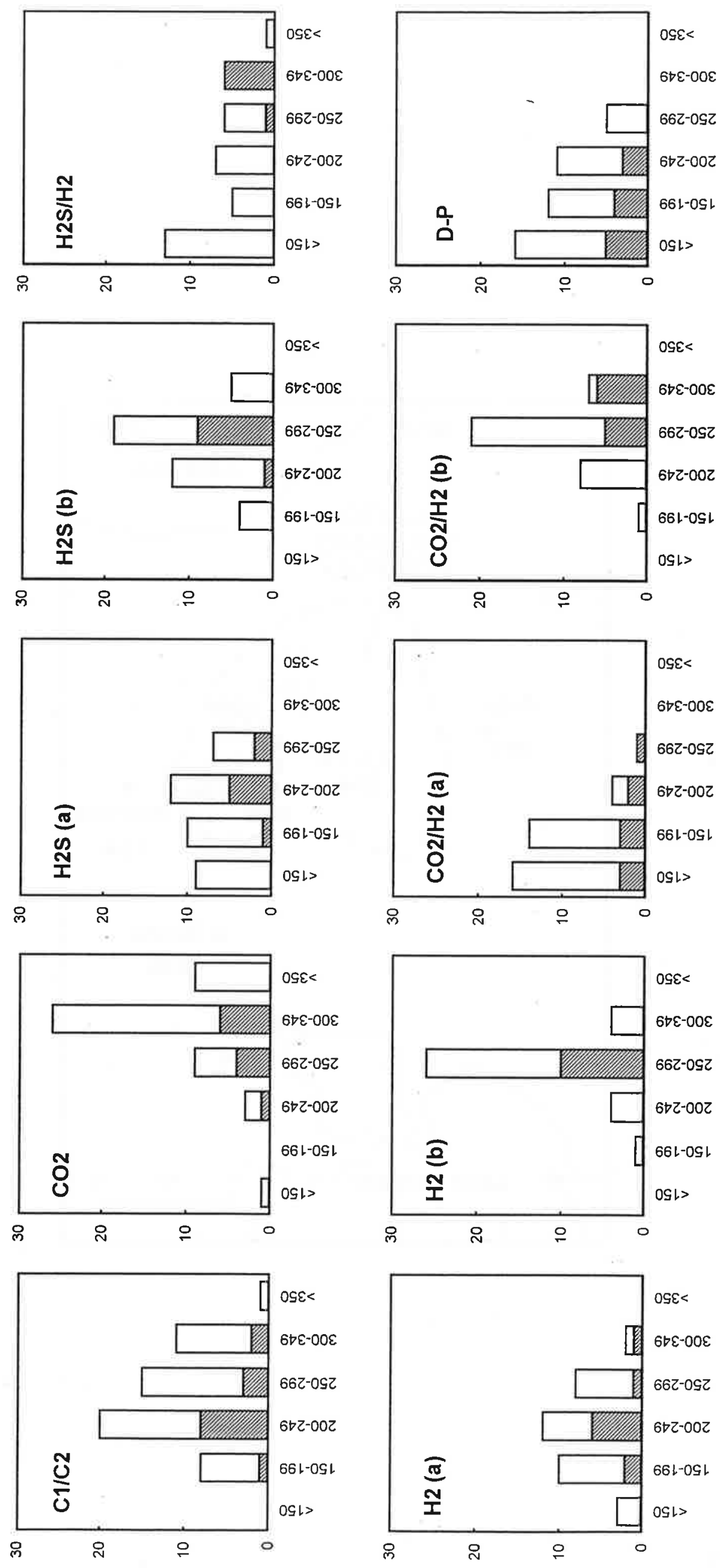


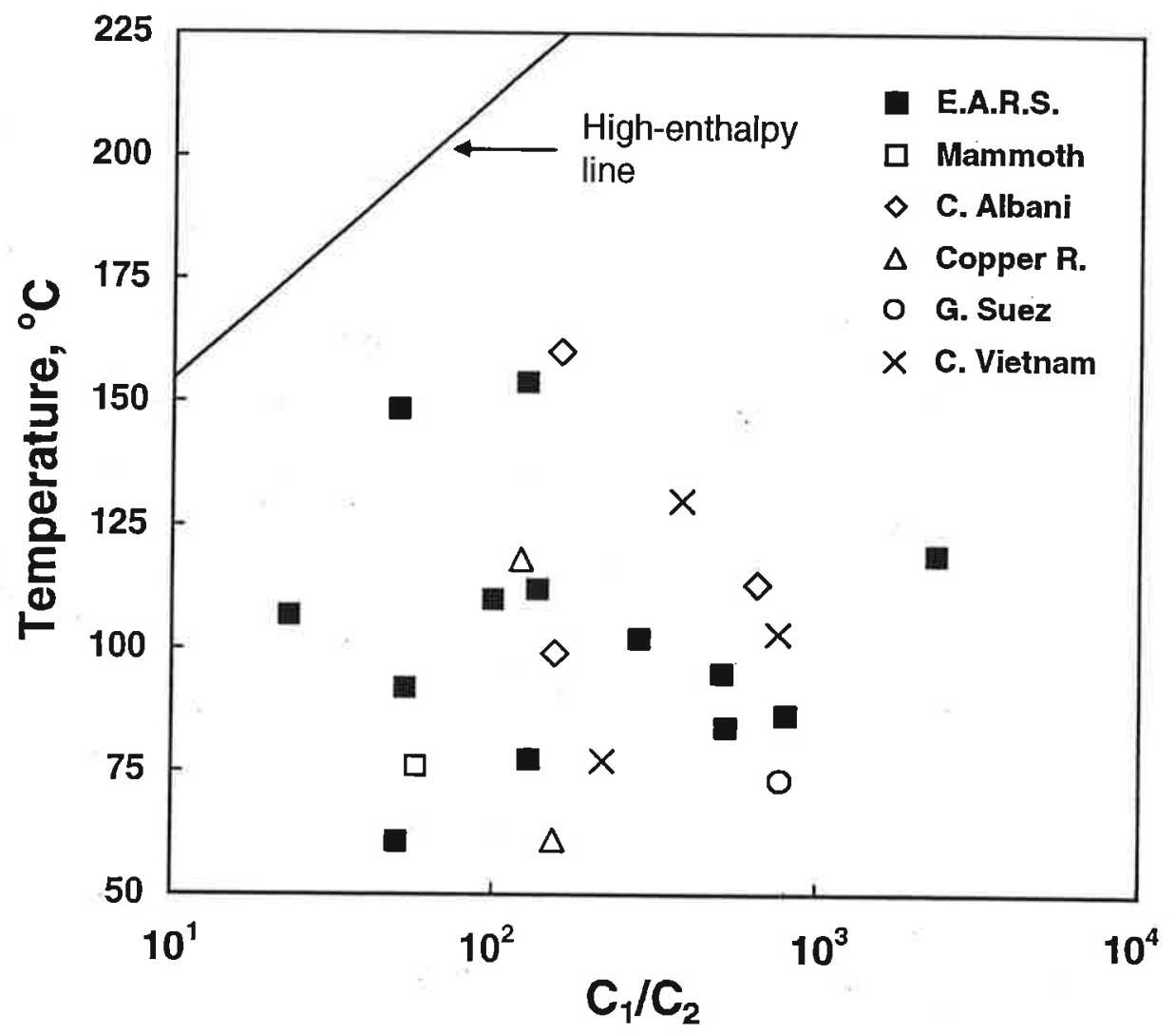

Fig 12 
